\title{
Inconsistent Retirement Timing
}

\author{
Christoph Merkle, Philipp Schreiber, and Martin Weber*
}

\begin{abstract}
We study the effect of inconsistent time preferences on actual and planned retirement timing decisions in two independent datasets. Theory predicts that hyperbolic time preferences can lead to dynamically inconsistent retirement timing. In an online experiment with more than 2,000 participants, we find that timeinconsistent participants retire on average 1.75 years earlier than time-consistent participants do. The planned retirement age of non-retired participants decreases with age. This negative age effect is about twice as strong among time-inconsistent participants. The temptation of early retirement seems to rise in the final years of approaching retirement. Consequently, time-inconsistent participants have a higher probability of regretting their retirement decision. We find similar results for a representative household survey (German SAVE panel). Using smoking behavior and overdraft usage as time preference proxies, we confirm that timeinconsistent participants retire earlier and that non-retirees reduce their planned retirement age within the panel.
\end{abstract}

\footnotetext{
${ }^{*}$ Christoph Merkle is an associate professor of finance at Aarhus University and a research fellow at the Danish Finance Institute (corresponding author: cmerkle@econ.au.dk). Philipp Schreiber is a full professor of finance at Esslingen University. Martin Weber is a senior professor of finance at the University of Mannheim and a research fellow at the CEPR. We are grateful to the Frankfurter Allgemeine Zeitung for their collaboration in conducting the study. Intensive discussion with two journalists, Anne-Christin Sievers and Patrick Bernau, helped to considerably improve the questionnaire. We further thank Shlomo Benartzi, Scott Findley, Antonia Grohmann, Pieter Verhallen, participants of the SABE 2020 Annual Conference, the Netspar International Pension Workshop 2019, the EEA 2018 Annual Meeting, and seminar participants in Aarhus and Mannheim for their valuable suggestions. Support from the Danish Finance Institute is gratefully acknowledged. Data and programs for replication are available at https://doi.org/10.6084/m9.figshare.17203757.v1. The replication files do not include the SAVE data, which are freely available for researchers after registration at The Max Planck Institute for Social Law and Social Policy at https://www.mpisoc.mpg.de/en/socialpolicy-mea/research/save-2001-2013.

JEL Classification: D14, D15, D91, H55, J18, J22, and J26.

Supplementary materials are freely available online at: http://uwpress.wisc.edu/journals/journals/jhrsupplementary.html
} 


\section{Introduction}

When to retire is one of the most important financial decisions in later life that almost everyone has to take. Income during retirement highly depends on retirement timing. In most countries, social security benefits are paid according to years of work and income during employment. In these systems, earlier retirement results in lower retirement benefits. The retirement timing decision becomes even more important as life expectancy increases. For example, the average number of years spent in retirement by men in the United States has increased from eight years in 1950 to almost twenty years in 2020. Accepting a reduction in retirement benefits, therefore, affects the financial well-being of a retiree for a substantial period of time.

Early retirement does not only have consequences on a personal level but also affects the pension system as a whole. Increasing life expectancy combined with low birth rates put the pay-as-you-go social security systems of many developed countries under pressure. Retirement timing is an important determinant of the ratio between contributors and recipients within the system. Policy attention to this issue has grown recently. The European Commission (2012) highlights the importance of creating an environment that encourages older workers to remain part of the workforce in a white paper on adequate, safe, and sustainable pensions. To develop appropriate strategies in this regard, it is necessary to understand the drivers of individual retirement timing.

The retirement timing decision is an intertemporal consumption decision under uncertainty for which time preferences play an important role. They can be interpreted as individuals' valuation of a good at an earlier date compared to its valuation on a later date (Frederick, Loewenstein and O'Donoghue, 2002). A decision-maker with hyperbolic time preferences exhibits higher discount rates for the near future and lower rates for the more distant future. Such preferences can lead to dynamically inconsistent decisions. For example, DellaVigna and Malmendier (2006) analyze gym membership contracts and find that the 
majority of gym members plan to attend on a regular basis when signing the membership contract. However, actual attendance over the lifetime of the contract turns out to be much lower.

In the retirement context, time-inconsistent decision-makers schedule an optimal retirement age during work life. However, when the retirement age approaches, they re-evaluate this plan and choose to retire earlier or later. We focus on the case of unplanned earlier retirement and, from now on, use the term "time-inconsistent preferences" synonymously with hyperbolic or present-biased preferences (excluding other forms of inconsistency such as future bias). A preference revision may have undesirable financial consequences, in particular, if decision-makers are naïve about it. As commonly defined, naïve hyperbolic discounters overestimate their future self-control, while sophisticated hyperbolic discounters are aware of potential future preference reversals.

Theoretical studies model the savings and retirement timing decision of hyperbolic agents when retirement is endogenous (Diamond and Köszegi, 2003; Zhang, 2013; Findley and Caliendo, 2015), which allows us to derive predictions for retirement timing. Hyperbolic discounting (in contrast to exponential discounting) can lead to dynamically inconsistent earlier retirement. The decision-maker initially plans to retire on a certain date, but by placing too much weight on the near future will prefer to retire early when the retirement date approaches. Future consumption is, in this case, traded against immediate leisure. However, hyperbolic discounting at the same time predicts undersaving. A hyperbolic decision-maker might not have accumulated sufficient wealth to afford early retirement and is forced to retire later (Diamond and Köszegi, 2003). The direction of the total effect is, therefore, an empirical question.

We collect evidence from two independent datasets. We obtain the first dataset in an online experiment in cooperation with a large German newspaper. We recruit more than 2,000 participants, who are classified as time consistent or time inconsistent based on an intertemporal choice task. Using the example of a tax refund, they are offered several choices 
of a smaller sooner or a later larger amount. Participants also answer a series of questions regarding their retirement plans and expectations. They indicate their planned retirement age if they are not yet retired or their actual retirement age if they are already retired. The experiment further includes questions on risk preferences, loss aversion, financial literacy, impatience, and subjective life expectancy.

For the subsample of retired participants, we find that retirees, who can be classified as time inconsistent, retired on average 1.75 years earlier than time-consistent participants. This demonstrates that inconsistent time preferences may have severe consequences for retirement timing. The result holds after controlling for impatience, which also predicts earlier retirement but does not imply time inconsistency. Moreover, we find that time-inconsistent participants are on average more than twice as likely to regret their retirement timing decision. $34 \%$ of the time-inconsistent participants state that they would retire later if they could decide again.

For the larger subsample of not yet retired participants, we focus on the relation between time preferences and planned retirement age. Inconsistent time preferences may lead to a decreasing planned retirement age with advancing age of the decision-maker. The rationale is an increasing temptation to retire as the planned retirement date approaches. We find evidence for this prediction as participants' age has a significantly negative effect on planned retirement age. Time-inconsistent participants, on average, plan to retire up to one month earlier by each year they get older. This negative age effect is about twice as large as found for time-consistent participants and kicks in above age 50. The pattern of results is consistent with predictions of hyperbolic discounting, which provide evidence for the role of time preferences in adapting retirement plans.

We further explore the financial consequences of the dynamically inconsistent retirement decision. The German social security system allows contributors to retire earlier with reduced monthly benefits. We find that participants, who plan to retire early from a young age, compensate for this reduction by buying private pension insurance. However, earlier retirement 
is unplanned from the perspective of a young or middle-aged person with time-inconsistent preferences. Therefore, it does not increase the likelihood of owning private pension insurance for this group, and a reduction in social security benefits remains largely uncompensated. In the German social security system, our results imply, on average, a 10\% lower level of monthly retirement benefits for time inconsistent retirees. This suggests that the nature of individual time preferences strongly influences participants' financial budget in retirement.

As a second dataset, we use a German household survey (SAVE panel) to corroborate the obtained results. It complements the experimental data as it provides a representative sample and the opportunity to analyze the dynamics of planned retirement with panel data. Specifically, the panel structure allows us to rule out possible cohort effects. While the SAVE household survey includes questions on planned and actual retirement, it lacks a direct measure of time preferences. Instead, we use smoking habits and bank account overdraft usage as proxies for time inconsistency.

With the help of these proxies, we can confirm the experimental results for planned and actual retirement age (controlling for health effects). Time-inconsistent participants retire significantly earlier, and the economic magnitude of the effect is comparable to the experimental results. The analysis of the panel shows that time-inconsistent non-retirees significantly decrease their planned retirement age over time. The fraction of participants who retire earlier than planned is also higher for time-inconsistent participants.

By measuring individuals' time preferences and analyzing their effect on retirement timing, we contribute to a growing literature in behavioral economics on retirement savings and planning (Benartzi and Thaler, 2007). Framing and its impact on retirement timing is perhaps the phenomenon studied most extensively, with the common finding that the retirement decision is strongly affected by how information is presented (Fetherstonhaugh and Ross, 1999; Brown, Kapteyn and Mitchell, 2013; Shu, Payne and Sagara, 2014; Merkle, Schreiber and Weber, 2017). Non-standard time preferences, alongside affective forecasting and planning fallacy, fall into a category of issues in predicting future behavior and happiness 
(for an overview, see Knoll, 2011). While altering decision frames in the form of nudging has prominently reached the policy debate, we point out how inconsistent time preferences interact with policy interventions. In particular, we discuss recent trends to increase flexibility in retirement systems and the potential creation of commitment devices.

\section{Time Preferences and the Retirement Decision}

\section{A. Time Preferences: Hyperbolic Discounting}

Discount functions are commonly used to formalize time preferences and to express how decision-makers value consumption or payments at different points in time. The strength of discounting hereby depends on the individual level of impatience, which is mostly considered a fixed characteristic of a person. A standard assumption for discount functions is stationarity, which implies that discount rates are the same for time periods of the same lengths (Halevy, 2015). The only discount function fulfilling this assumption is the exponential discount function. However, empirical and experimental studies find that people often exhibit higher discount rates for outcomes in the near future and lower discount rates for outcomes in the more distant future (Thaler, 1981; Frederick, Loewenstein and O'Donoghue, 2002). This pattern in time preferences can be described by a hyperbolic discount function.

A functional form of the hyperbolic discount factor is $D F(t)=(1+\alpha t)^{-\frac{\gamma}{\alpha}}$ with parameters $\alpha, \gamma>0$ (Loewenstein and Prelec, 1992). Compared to the exponential function, the hyperbolic function discounts the immediate future more strongly and becomes rather flat for the distant future. Just as the exponential discounting function, it can encode different levels of individual impatience. Due to its functional form, the average hyperbolic discounter will be more impatient for the near future and more patient for the more distant future.

In many theoretical models, a quasi-hyperbolic discount function is used. The concept of quasi-hyperbolic discounting has been introduced by Phelps and Pollak (1968) and formalized by Laibson (1997). The quasi-hyperbolic discount factor is a discrete-time function $D F(t)=$ 
$\beta \delta^{t}$ and $D F(0)=1$, with $\delta$ and $\beta$ between 0 and 1 . It combines most features of the hyperbolic discount function with good analytical tractability. In particular, the parameter $\beta$ introduces present bias as all future outcomes are additionally discounted relative to the present. However, a relevant feature of the general hyperbolic discount function is absent in quasi-hyperbolic discounting: the non-stationarity of time preferences for future outcomes. ${ }^{1}$ While a hyperbolic discounter becomes gradually more impatient when outcomes get closer in time, for the quasi-hyperbolic discounter this is not the case as long as all outcomes remain in the future (sometimes called quasi-stationarity, Montiel Olea and Strzalecki, 2014).

Hyperbolic (and quasi-hyperbolic) time preferences can lead to dynamically inconsistent decisions (Laibson, 1997; O’Donoghue and Rabin, 1999). For example, a worker might prefer a 20-minute break in 101 days over a 15-minute break in 100 days, but as time passes, reverse the decision in favor of a 15-minute break today instead of a 20-minute break tomorrow (Laibson, Repetto and Tobacman, 1998). Dynamic inconsistency arises when a decisionmaker chooses an optimal plan at a point in time $t$ but re-evaluates this plan at a later point in time $t+s$ and does not stick to it. Time inconsistencies arise by a change in the used discount factor when time progresses, not by a change of the discount function itself, which is assumed to be stable within person.

Experimental studies reveal such time inconsistencies by providing sets of choices between sooner smaller rewards and later larger rewards with different delays of the sooner reward (Green, Fristoe and Myerson, 1994; Kirby and Herrnstein, 1995; Ahlbrecht and Weber, 1997; Coller and Williams, 1999; Meier and Sprenger, 2010). They show preference reversals, as with longer delays, the later larger reward typically becomes more attractive. Another approach is to follow participants longitudinally and let them take the same decision once ahead of time and once at the time of consumption (Ainslie and Haendel, 1983; Read and van Leeuwen, 1998; Sayman and Öncüler, 2009; Halevy, 2015). A common finding is that some (but not all participants) show time inconsistent preferences. There is evidence for

\footnotetext{
${ }^{1}$ For a detailed description of the differences between discount functions, see Online Appendix A.
} 
experimental measures of time preferences to predict behavior outside the laboratory (Meier and Sprenger, 2010, 2012; Sutter et al., 2013), even though not all studies find such a link (Rohde, 2019). ${ }^{2}$ There is also evidence that empirically measured time preferences are to a similar degree stable as other personality measures (Kirby, 2009; Meier and Sprenger, 2015; Falk et al., 2016).

An important distinction is whether a decision-maker is aware of time-inconsistent preferences or not (sophisticated vs. naïve, O’Donoghue and Rabin, 1999). A naïve decision-maker does not anticipate the urge to change the original plan in later periods. In contrast, a sophisticated decision maker anticipates a lack of self-control and tries to pre-commit to a course of action if possible (Strotz, 1955; Thaler, 1981). Commitment devices can help a sophisticated decision-maker to stick to a plan identified as optimal. Examples for the real-world demand of commitment devices have been found in the financial and non-financial domain (Ashraf, Karlan and Yin, 2006; DellaVigna and Malmendier, 2006).

\section{B. The Retirement Decision}

Hyperbolic decision-makers place more weight on the near future. In the retirement context, this can have two opposing effects: On the one hand, hyperbolic decision-makers prefer immediate consumption and save less during their work life. As a consequence, they might have to work longer before they can afford to retire than exponential decision-makers (Laibson, 1997). On the other hand, the retirement timing decision itself represents a trade-off between immediate leisure and future consumption. Approaching retirement, hyperbolic decision-makers are tempted to retire earlier since they weight the utility gained from immediate leisure highly relative to the utility loss due to reduced future consumption. For a given level of savings, a hyperbolic decision-maker is thus more likely to retire early.

\footnotetext{
${ }^{2}$ It is beyond the scope of this paper to provide a complete summary of the large literature on time preferences (for critical reviews, see, e.g., Frederick, Loewenstein and O'Donoghue, 2002; Sayman and Öncüler, 2009; Sprenger, 2015; Rohde, 2019). We will also mostly bypass a discussion of present bias, i.e., the overvaluation of immediate rewards (see, e.g., Lynch and Zauberman, 2006; O'Donoghue and Rabin, 2015).
} 
Diamond and Köszegi (2003) examine the effect of an endogenous retirement decision on savings behavior in a model with quasi-hyperbolic time preferences. In a three-period setting, an agent works in period -1 , decides whether to work or to retire in period 0 , and is retired in period 1 . Working in period -1 provides income, which can be consumed or saved. As a result of saving, the agent holds wealth $W_{0} \geq 0$ in period 0 . Working in period 0 produces additional income of $\Delta$, but costs effort of $e>0$. In periods 0 and 1 , the agent can thus consume $W_{0}$ if retiring or $W_{0}+\Delta$ if working. Diamond and Köszegi (2003) show that there are wealth levels, $W_{0}$, for which the agent initially plans to retire late but, as period 0 arrives, re-evaluates this plan and chooses to retire earlier. Quasi-hyperbolic utility can thus produce dynamically inconsistent retirement timing.

Sophisticated agents anticipate their inconsistent future behavior and can devise two different strategies to prevent it: Either they reduce savings in period -1 that wealth $W_{0}$ is sufficiently low to force the period-0-self to work ("strategic undersaving"), or they increase savings that both the self in period -1 and 0 prefer to retire early. Whether quasi-hyperbolic discounting leads to early retirement, therefore, depends on the level of accumulated savings.

Empirically, both undersaving and early retirement are observed. For example, in the U.S., the majority of employees choose to retire earlier than the full retirement age (Gruber and Wise, 2004; Behaghel and Blau, 2012). Simultaneously, savings rates are declining, and many Americans report that they are saving too little for retirement (Choi et al., 2002; Benartzi and Thaler, 2013). ${ }^{3}$ Present-biased time preferences have been found to be a factor in lower retirement savings (Goda et al., 2019).

To explain these findings, Zhang (2013) studies a model that differs from Diamond and Köszegi (2003) in three major ways: First, the decision-maker chooses a continuous labor supply in period 0. Second, both naïve and sophisticated agents are taken into account, and finally, early retirement and undersaving are defined relative to a decision-maker who discounts exponentially. She derives conditions under which quasi-hyperbolic discounting

\footnotetext{
${ }^{3}$ The common interpretation is that undersaving occurs because of limited self-control, inertia, or lack of means to save. The empirical relevance of strategic undersaving remains unclear.
} 
can lead to a co-existence of undersaving and early retirement. The result depends on utility functions and discounting parameters, and it holds for naïve as well as for sophisticated agents.

Findley and Caliendo (2015) study the effect of hyperbolic discounting on savings behavior in a continuous-time model with endogenous retirement. They focus on naïve decisionmakers and compare them to exponential discounters. They find that hyperbolic discounters plan to retire early but then have to postpone retirement due to insufficient savings. The hyperbolic agent fails to stick to original retirement plans, but the resulting time inconsistency is different from the outcome of the other models. They document the possibility of delayed retirement arising from hyperbolic time preferences.

Besides these theoretical models, a broad literature studies structural life-cycle models and labor supply (see Blundell, French and Tetlow, 2016, for a review). As structural approaches can accommodate many features of social security systems, they are a powerful tool for policy analysis. However, these models are almost exclusively estimated with timeconsistent preferences (an exception is Gustman and Steinmeier, 2012), which is why we do not derive hypotheses from them. We will point out the potential effect of introducing inconsistent time preferences into such structural models in the discussion of policy measures.

\section{The German Public Pension System in Brief}

The German public pension system is one of the oldest in the world and was introduced already in 1889. It covers private-sector employees and public-sector employees except for civil servants, liberal professions, and self-employed persons. During the employment phase, employees, as well as employers, contribute to social security proportional to wage (with a cap). Employees accumulate earnings points that, together with their retirement age, determine the amount of retirement benefits. Unlike in the U.S., all years of earnings count for retirement benefits. 
The German social security system stipulates a regular or full retirement age (FRA), as well as an early retirement age. A reform in 2007 shifted the FRA from 65 to 67 , which is implemented gradually depending on birth year. The replacement rate at FRA was around $50 \%$ (before taxes) during the survey period. Early retirement is possible up to four years before the full retirement age with a $3.6 \%$ p.a. reduction of retirement benefits. ${ }^{4}$ Late retirement is also possible with a $6 \%$ p.a. premium on retirement benefits. Besides the regular old-age pension, social security covers disability pension and survivors' pension.

\section{Hypotheses}

According to the presented theory, hyperbolic discounting can have a direct and an indirect effect on retirement timing. The direct effect predicts earlier than planned retirement as hyperbolic discounters are tempted to trade future consumption against immediate leisure. Approaching retirement, it becomes more attractive to avoid the additional effort costs associated with working. The indirect effect, however, goes in the opposite direction as hyperbolic time preferences increase the utility of immediate consumption relative to saving for future consumption. Hyperbolic discounters might not have accumulated sufficient savings to finance early retirement and therefore need to work longer.

We study the empirical relation between inconsistent time preferences and the retirement decision in Germany. The social security system functions as a commitment device by forcing employees to save a relatively high share of their income. As a result, German retirees heavily rely on retirement benefits and regard private savings rather as an add-on (70\% of retirement income in Germany comes from public transfers, OECD, 2017). We can confirm in the data that participants expect to obtain a relatively high level of retirement benefits. This mitigates at least to some extent the problem of undersaving. We thus hypothesize that the direct effect will dominate in societies with a strong social security system:

\footnotetext{
${ }^{4}$ For a detailed calculation of financial losses associated with early retirement, see Online Appendix B.
} 


\section{H1: Time-inconsistent decision-makers will retire earlier than time-consistent}

decision-makers.

It is important to distinguish the effect of time inconsistent preferences from mere impatience. Impatience implies a higher discount rate and is compatible with both exponential discounting and hyperbolic discounting. More impatient decision-makers are likewise predicted to retire earlier. However, the two effects should be independent, as inconsistent time preferences rely on the specific significance of the present and near-future relative to the more distant future.

H1a: Higher impatience will result in earlier retirement, but its impact is distinct from the effect of time inconsistency.

In particular, more impatient but time-consistent decision-makers will not regret their decision, as their perspective on the decision is stationary when time progresses. On the other hand, time-inconsistent preferences might lead to a later re-evaluation of the decision with a different outcome. This allows us to sharpen the distinction between time inconsistent preferences and the degree of impatience.

H2: Time-inconsistent decision-makers are more likely to regret their decision than time-consistent decision-makers.

H2a: The degree of impatience has no impact on decision regret.

Inconsistent time preferences do not only influence the final retirement decision but ongoing retirement plans as well. When coming closer to retirement, a hyperbolic agent approaches the steeper part of the discount function and will feel increasingly tempted to retire earlier and may reduce the planned retirement age. This results in our third hypothesis:

H3: The planned retirement-age of time-inconsistent decision-makers will decrease with increasing age. 
Notably, this age effect is absent for consistent time preferences due to stationarity. Impatience per se does not produce such an effect. Likewise, the quasi-hyperbolic model does not predict a decrease in planned retirement age since time preferences are stationary except for period 0 (see Online Appendix A). However, a number of other factors might induce a revision of one's planned retirement age. For example, older individuals have less uncertainty about their future life expectancy. In the empirical analysis, we control for subjective life expectancy and impatience. We further control for demographics, risk aversion, loss aversion, and many other variables.

The idea of time-inconsistent retirement plans is supported by Bidewell, Griffin and Hesketh (2006), who conduct an experiment in which participants choose between early and late retirement depending on hypothetical savings, enjoyment of retirement, and chances of good health during retirement. They find that participants, who are closer to their planned or expected retirement age, are more tempted and are willing to give up more of their future retirement income in order to retire early. They attribute this finding to stronger discounting, however, not explicitly to hyperbolic discounting. Yet this is in line with hyperbolic time preferences, as the functional form of the discount factor predicts stronger discounting and increasing temptation the closer an event. For the observed age effect, we thus formulate as an additional hypothesis:

H3a: The negative effect of age on planned retirement age is more pronounced for decision-makers closer to retirement.

A final question is whether decision-makers are sophisticated about this gradual reduction in planned retirement age. If so, they might buy additional pension insurance to compensate for the expected loss in benefits. In contrast, if decision-makers are naïve, the reduction in planned retirement age will come as a surprise and find them unprepared. While this is ultimately an empirical question, we give participants the benefit of the doubt and assume sophistication: 


\section{H4: Time-inconsistent decision-makers anticipate earlier retirement and increase their retirement provisions already when young.}

\section{Experimental Design and Data}

\section{A. Experimental Design}

We conduct an online experiment in cooperation with a large and well-circulated German newspaper, the Frankfurter Allgemeine Zeitung (FAZ). Participants are recruited via a link on the newspaper's website and two announcements in the print edition. In total, 3,077 participants complete the experiment, which takes them on average 11 minutes. Participants answer questions about retirement planning, time preferences, risk preferences, financial literacy, and demographics. Some participants are assigned to different branches of the experiment, which are analyzed in two papers that use data from the same survey (Schreiber and Weber, 2016; Merkle, Schreiber and Weber, 2017). Therefore the initial sample for this study consists of 256 retired participants and 2,173 non-retired participants.

The main dependent variables are actual or planned retirement age. First, participants are asked whether or not they have already retired. Depending on their response, we ask participants "At what age did you retire?" or "At what age do you plan to retire?", respectively. The question for actual retirement age does not specify whether participants retired to receive regular old-age pension or disability pension (which covers about $10 \%$ of retirees). It is plausible that retirement due to illness or disability is less or not at all affected by time preferences. Not being able to exclude these cases will most likely weaken our results.

To distinguish between time-inconsistent and time-consistent participants, we use decisions between an earlier and a later monetary reward, which is a standard elicitation procedure in economics at least since Thaler (1981). According to a recent review, $60 \%$ of all empirical articles in the time preference literature use a version of the money earlier or later design (Cohen et al., 2020). Participants in our survey make six choices about when 
to receive a tax refund, which are displayed in Figure 1. The choices always offer a smaller sooner refund and a later larger refund. Decisions with similar stakes and time delays have been introduced in broad population surveys (Harrison, Lau and Williams, 2002; Andersen et al., 2008). To measure time inconsistency, each choice is paired with a time-delayed version of the same choice (Sayman and Öncüler, 2009; Meier and Sprenger, 2010). For this reason, half of the choices involve decisions between a refund today and in ten months, while the other half is between a refund in 18 months and 28 months. The three questions within each set differ in the annual interest rate $i$, which takes the values $3.3 \%, 11.3 \%$, and $31.3 \%$.

If participants had time-consistent preferences, only the time difference between the two options would matter, which is the same for all questions (10 months). Time-consistent participants make the same decision (earlier or later payment) independent of whether the earlier payment takes place today or in 18 months. Hyperbolic decision-makers, however, value the immediate payment more highly relative to the payment in 10 months than they do if all payments are delayed by 18 months. It is likely that a hyperbolic discounter will switch decisions for at least one interest rate level. ${ }^{5}$ Participants' choices are classified as inconsistent if they prefer the earlier payment in the choice involving the immediate payment and the later payment in the delayed choice. We define a measure for time-inconsistent preferences that counts the number of inconsistent answers ranging from 0 to 3.

\section{B. Control variables}

We carefully select control variables consulting the broad literature on retirement timing and factors that delay or accelerate retirement. ${ }^{6}$ Among analyzed factors that influence retirement timing are health (Bazzoli, 1985; McGarry, 2004; van Rijn et al., 2013), economic status (Kim and Feldman, 1998; Madero-Cabib, Gauthier and Le Goff, 2015), gender (Finch, 2014), age (Kim and Feldman, 1998), education (DePreter, Looy and Mortelmans, 2015;

\footnotetext{
${ }^{5}$ In Online Appendix C, we discuss the occurrence of such switches depending on the discount function.

${ }^{6}$ For detailed reviews of this literature, see Beehr and Bennett (2015) and Fisher, Chaffee and Sonnega (2016).
} 
Woehrmann, Brauner and Michel, 2020), subjective life expectancy (Griffin, Hesketh and Loh, 2012; Heimer, Myrseth and Schoenle, 2019), marital status (Gustman and Steinmeier, 2000), and childbearing (Hank, 2004). We thus collect information about gender, age, marital status, number of children, subjective life expectancy, and education. Economic status is captured by income for non-retirees and retirement benefits for retirees. For exact definitions of the variables, see the Appendix.

We lack information on health and wealth, as these were considered sensitive in the context of a voluntary survey. Due to limited survey length, we also do not have detailed data on job characteristics (Wang and Shultz, 2010; Earl and Taylor, 2015) or spousal labor and retirement choices (Schirle, 2008). It is thus possible that our regression analysis suffers from some degree of omitted variable bias. To get an indication of the severity of the problem, we will use the methodology introduced by Oster (2019).

The set of control variables further includes measures of impatience, risk and loss aversion, and financial literacy. Impatience is measured as the agreement to the statement "I am an impatient person" on a seven-point Likert scale. Risk and loss aversion are both self-reported and elicited on a seven-point Likert scale, as well. Participants indicate whether they agree to the statements "I am a risk-averse person" and "I am very afraid of losses," respectively. There is evidence that self-reported preferences are good predictors of choices (Nosić and Weber, 2010; van Rooij, Lusardi and Alessie, 2011; Merkle, Schreiber and Weber, 2017).

Participants further answer a set of six financial literacy questions. Since the FAZ newspaper has a sophisticated readership, only one of the basic questions and three of the advanced questions by van Rooij, Lusardi and Alessie (2011) are used. We introduce two even more advanced questions (see Online Appendix D).

The experiment uses hypothetical choices, which allows us to recruit a large sample of participants, including employees of all ages and retirees. The decision when to retire lies in the nearer future for many participants, and we expect relevant answers to retirement-related questions. Rubinstein (2001) replicates more than 40 experiments without monetary rewards 
and, in almost all cases, finds no qualitative differences in results compared to incentivized experiments. For time preferences in particular, it has been found that hypothetical and real rewards usually produce similar responses (Cohen et al., 2020).

In addition, using real incentives in intertemporal choice can provoke participants to view future payments as uncertain, in particular, when the distance in time between the experiment and the actual payoff is large (e.g., up to 28 months in our survey). Therefore, a present-biased or hyperbolic discounting pattern can be generated even for participants with time consistent preferences (Read, 2005; Sutter et al., 2013). Secondly, monetary payments can create a self-selection problem by attracting participants who are in immediate need of money. This could also introduce a bias in the direction of hyperbolic discounting (Noor, 2009; Sutter et al., 2013).

\section{Summary Statistics}

We begin with a detailed description of participants' time preferences. As the final measure will be constructed by combining all six time-preference questions, we exclude observations with missing values $(n=104) .{ }^{7}$ Table 1 shows the responses of the remaining 2,325 participants separately for the sub-samples of retirees and non-retirees. Panel A shows how many participants choose the sooner smaller refund or the later larger refund for each question. As expected, the fraction of participants choosing the sooner refund decreases with the implicit interest rate. Furthermore, in all three decisions involving the immediate refund, the percentage of participants choosing sooner is higher than in the corresponding decisions with a time delay. This finding already suggests that some degree of present bias exists in both sub-samples.

Panel B summarizes results on the participant level. Around 60\% answer timeconsistently in all three questions, while the remaining participants are mostly time-

\footnotetext{
${ }^{7}$ Missing values are more frequent in the sample of retirees. One reason might be that the time preference questions were asked at a later point in the survey for this group. Additionally, retirees might regard a tax refund as irrelevant to them as, until recently, most retirees did not pay taxes on social security benefits in Germany.
} 
inconsistent in the direction of present bias or hyperbolic discounting. This means that they prefer the sooner refund in the decision without delay and the later refund in the decision with delay. We distinguish participants with one, two, or three inconsistent answers and find that one inconsistent answer is most common in both sub-samples.

There are rare cases of time inconsistencies in the other direction $(n=21)$, which can be labeled "future bias" or "reverse time inconsistency" (Sayman and Öncüler, 2009). As these observations account for less than $1 \%$ of the sample, they are excluded, and we do not analyze them any further. Even though other studies find higher rates of future bias (Takeuchi, 2011; Montiel Olea and Strzalecki, 2014), it remains unclear whether such findings robustly correlate with behavioral outcomes (Stango and Zinman, 2019). Finally, some participants show both behaviors, present bias in one question and future bias in another $(\mathrm{n}=6)$. These observations are also excluded. The low rate of mixed bias and high sensitivity to interest rates suggests that participants answer the questions diligently, which should reduce measurement error. The final sample consists of 187 retirees and 2,111 non-retirees.

For further analysis, we capture time inconsistency in two variables: an inconsistency indicator that takes a value of one if at least one question is answered inconsistently and the number of inconsistent answers ranging from zero to three. The three pairs of questions cannot perfectly identify time-inconsistent preferences as there are some parameter combinations for hyperbolic and quasi-hyperbolic discount functions that produce zero switching (see Online Appendix C). The indicator may thus understate the prevalence of time-inconsistent preferences. Such measurement error is inevitable when eliciting continuous preference parameters using a discrete grid of choices (Falk et al., 2016). Misclassifications will add noise to the analysis and can lead to attenuation bias. As displayed in Table 2, the average number of inconsistent answers is around 0.6 in both samples (and around 1.6 conditional on being time inconsistent). We interpret this count of inconsistent answers as a measure for the strength of time inconsistency, as a higher number of inconsistent choices requires more pronounced (quasi) hyperbolic discounting. Participants are moderately impatient and im- 
patience is only weakly correlated with the number of inconsistent answers given (0.20 for retirees [n.s.], 0.03 for non-retirees [n.s.]).

The average planned retirement age is close to the former full retirement age in Germany (65). The actual retirement age of retirees in the survey is 61.8 , which is not significantly different from the average retirement age in Germany at the time of the survey. ${ }^{8}$ The difference between the planned and actual retirement age may indicate that employees adjust their plans downward when approaching retirement. To some extent, it may also represent a cohort effect. $21 \%$ of retired participants believe that they retired too early.

The average age in the sample is 40 years. Men are overrepresented (85\% male), reflecting the fact that the majority of FAZ readers are male. Moreover, the FAZ sample can be classified as educated and high income. Participants report an average monthly net income of EUR 3,410, which is about the German average gross income at the time of the survey. ${ }^{9}$ $91 \%$ of participants received the German equivalent to a high school diploma, and $66 \%$ graduated from a university. About half of the participants are married.

Table 2 also includes the additional control variables. The questions for risk aversion and loss aversion reveal that participants judge themselves as somewhat more loss averse than risk averse. As expected, participants do well in the financial literacy task with an average of 4 correct answers (out of six). Participants estimate their life expectancy on average to be close to 84 years, and about $66 \%$ (of non-retirees) own private pension insurance. We run regressions of time preference measures on demographic variables and controls to identify correlations (see Online Appendix C). We find an increase in time-inconsistent responses with age and a decrease in inconsistent responses with education and financial literacy. However, the economic magnitude of these effects is rather small.

\footnotetext{
${ }^{8}$ Average age at which a person first received an old-age pension: 61.1. Source: Eurostat (http://appsso. eurostat. ec. europa.eu/nui/show. do?dataset=lfso_12agepens\&lang=en); retrieved 11/22/2017.

${ }^{9}$ Source: German Federal Statistical Office (www.destatis.de/DE/ZahlenFakten/ GesamtwirtschaftUmwelt/VerdiensteArbeitskosten/VerdiensteVerdienstunterschiede/Tabellen/ Bruttomonatsverdienste.html); retrieved 11/27/2017.
} 


\section{Results}

\section{A. Results for Actual Retirement Age}

We first examine the relation between time preferences and the actual retirement age. Timeconsistent participants in our sample retired with 62.2 years on average (see Figure 2). The number of inconsistent answers in the time preference questions turns out to be related to retirement timing: answering all three questions inconsistently is associated with significantly lower actual retirement age. The effect size is economically meaningful. While mildly time inconsistent retirees retired on average one year earlier than time consistent retirees, participants who answer all three questions inconsistently retired a staggeringly 3.8 years earlier (statistically significant at the $1 \%$-level).

Table 3 reports results for actual retirement age in a multivariate setting. Column (1) includes an inconsistency indicator as the single explanatory variable. Time inconsistent participants retired 1.76 years earlier than time consistent participants, which represents an average of the magnitudes displayed in Figure 2. As the figure shows an increase of the effect with the number of inconsistent answers, we switch to the count of inconsistent answers in column (2). An additional inconsistent answer implies earlier retirement of about 1.1 years. The effect decreases slightly with the inclusion of further control variables in columns (3)-(5) but remains robust with a coefficient between -0.98 and -1.03 .

Adding impatience in column (3) is of particular interest from the perspective of time preferences. Impatience has a negative effect on actual retirement age, with one point on the scale accounting for an earlier retirement of about $1 / 3$ of a year. As expected, more impatient participants retire earlier and trade off immediate leisure against future consumption. A jump from the middle to the end of the impatience scale has an effect of about the size of one additional time inconsistent answer. However, impatience does not crowd out the effect of inconsistent time preferences as both measures represent different aspects of time preferences. We can, therefore, simultaneously confirm Hypotheses 1 and 1a. 
The earlier retirement of time-inconsistent participants suggests that an indirect effect on retirement timing due to undersaving, if present, seems to be dominated by the direct effect. We explain this by the nature of the German social security system. Given the high mandatory contributions, there is less room for undersaving within the system. Social security benefits still represent the main source of retirement income (about $75 \%$ according to a report of the German government $)^{10}$ and undersaving outside the system may be of limited consequence. Time-inconsistent employees are in general able to afford earlier retirement. One can interpret the social security system as a commitment device for these people. In Online Appendix E, we provide additional tests for civil servants who receive more generous pensions. They tend to retire earlier and to follow their inconsistent time preferences more strongly.

In addition to time preferences, age, gender, retirement benefits, risk aversion, and financial literacy are (in some cases weakly) significant predictors of retirement age. The age effect is a mechanical effect as younger participants are only in the sample of retirees if they retired early. This does not imply that the younger cohort retires earlier in general. Participants who earn higher income retire earlier. Male participants retire 2.36 years later on average compared to female participants. These patterns have been previously observed in the literature (van Solinge and Henkens, 2010; Moen and Flood, 2013). In addition, we find that higher risk aversion leads to earlier retirement and that financial literacy, measured by the number of correct responses to the financial literacy questions, reduces the actual retirement age. This effect is not intuitive but is mainly driven by few retirees who answer only one or two out of the six questions correctly.

While coefficient stability after including controls is a common approach to evaluate robustness to omitted variable bias, Oster (2019) suggests a more formal approach. If the increase in the explained variation $\left(\mathrm{R}^{2}\right)$ is large relative to the change in effect size, it

\footnotetext{
${ }^{10}$ Source: Alterssicherungsbericht 2012, Bundesministerium für Arbeit und Soziales (report on retirement provision by the federal ministry of labour and social affairs), http://www.bmas.de/SharedDocs/ Downloads/DE/PDF-Gesetze/alterssicherungsbericht-2012.html; retrieved 11/28/2017.
} 
is unlikely that omitted variable bias is large. The test needs an assumption about the attainable $\mathrm{R}^{2}$, which we set at 1.5 times the $\mathrm{R}^{2}$ of the specification with all controls. Our criterion is stricter than the 1.3 times $\mathrm{R}^{2}$ threshold applied by Oster (2019), which already more than $40 \%$ of results from observational data do not survive. The measure $\delta$ for the effect of the number of inconsistent answers on actual retirement age is 4.2 in the specification with all controls (column (5) in Table 3). This means that the selection on unobservables would have to be more than 4.2 times larger than what we capture with the included controls for the effect of inconsistent answers to disappear. This is highly unlikely as the suggested cut-off is $\delta=1$.

\section{B. Retirement Regret}

When people follow their preferences, it is not obvious whether their behavior is harmful, even if these preferences are time-inconsistent. A criterion might be whether participants are satisfied with their retirement timing ex-post. Overweighting immediate leisure relative to future consumption could give rise to decision regret. We ask retired participants how they would decide if they could make the retirement timing decision again. They can choose whether they would retire later with higher social security benefits, retire earlier with reduced social security benefits, or make the same retirement decision again. To analyze retirement regret, we create an indicator variable Retirement Regret. It equals 1 if participants indicate that they retired too early and would retire later from today's perspective. The indicator equals 0 for participants who would not change their decision or would retire earlier.

Figure 3 shows a cross-tabulation of results for the number of inconsistent answers and the fraction of participants who indicate that they retired too early. Time consistency seems to matter: The fraction of participants stating they retired too early is significantly increasing with the number of inconsistent answers. In the group of retirees who are classified as time consistent, only $15 \%$ indicate that they would, in hindsight, choose to retire later. This 
fraction doubles for participants with 1 or 2 inconsistent answers and increases to $43 \%$ in the group with three inconsistent answers.

To substantiate these results, we run a linear probability model with retirement regret as the dependent variable. Table 4 presents the results of this analysis. In the first column, we again include time inconsistency as an indicator, which raises the propensity to regret retirement timing by about 19 percentage points up from a baseline of $15 \%$. Each time inconsistent answer has an effect of about 10 percentage points (columns 2-5). The effect is robust to the inclusion of impatience and further control variables. We confirm all results using logistic regressions, which are econometrically more appropriate but less easy to interpret (see Online Appendix F). In line with Hypothesis 2, we find a significant and economically strong effect of inconsistent time preferences on decision regret. It can be a result of an unplanned decision that is inconsistent with prior as well as subsequent preferences.

In contrast, the effect of impatience is insignificant in all regression specifications. The coefficient is close to zero and even switches signs when adding controls. While more impatient participants have been shown to retire earlier, they are not more likely to regret this decision. If participants are impatient but consistently so, they have no reason to change their minds about retiring early. This confirms the arguments brought forward for Hypothesis 2a. None of the remaining control variables has a significant effect on retirement regret. This suggests that no specific socio-demographic group is per se more likely to regret retirement timing. The measure for omitted variable bias is $\delta=2.9$ for inconsistent answers in the regression specification with all control variables.

\section{Results for Planned Retirement Age}

We next examine the planned retirement age of participants who are not yet retired. With a total of 1,974 observations, this subsample is much larger than the sample of retired participants. We use this sample to test Hypotheses 3 and 4 on how planned retirement evolves during one's work life. A univariate comparison reveals that participants with time-inconsistent 
preferences plan to retire on average about four months earlier than time consistent participants $(\mathrm{p}<.05)$. However, this overall effect deserves further scrutiny, as hyperbolic discounting predicts a reduction of planned retirement age over time rather than a lower planned retirement age in general.

Table 5 shows the multivariate relation between time preferences and planned retirement age. Columns (1) and (2) confirm an earlier planned retirement for time-inconsistent participants. Unsurprisingly, impatient participants also plan to retire earlier. Similar to the results for actual retirement age, the influences of time inconsistency and impatience coexist. They comprise different aspects of time preferences. The result for time inconsistency is robust to using the number of inconsistent answers as an alternative measure (columns (3) and (4)). In this case, the effect size is close to three months for each additional inconsistent answer. Stronger statistical significance implies that additional explanatory power comes from the extent of the inconsistency.

In column (5), we introduce age and the interaction between age and time inconsistency. Age has a negative effect on planned retirement age, which suggests that when employees get older, they reduce their planned retirement age. At least part of this result can be attributed to a cohort effect, as younger participants might reasonably expect they have to work longer given recent changes in the social security system. ${ }^{11}$ The interaction suggests that time-inconsistent participants reduce their planned retirement age even more than timeconsistent participants. The total effect on planned retirement age for this group is about one month for each year of age. Importantly, the interaction captures a good part of the main effect, which is no longer significant. This means that the effect of time inconsistency is not static but sets in and increases with advancing age.

Besides time preferences, coefficients for income and education are statistically highly significant. Participants with a higher income plan to retire earlier, which is in line with

\footnotetext{
${ }^{11}$ Cohort effects should matter less for the comparison between time-consistent and time-inconsistent participants as it mainly involves people of the same age. Nonetheless, any inference drawn from a crosssection of behavior over time needs to be interpreted with caution.
} 
findings by Munnell, Triest and Jivan (2004) and Li, Hurd and Loughran (2008). Participants with higher education plan to retire later, probably driven by higher job satisfaction (Helman, Copeland and VanDerhei, 2008). Additionally, education might enable a better understanding of the impact of retirement age on social security benefits, which could motivate a later planned retirement age (Coile et al., 2002). Quite intuitively, participants who buy private pension insurance plan to retire earlier.

In sum, we provide evidence for Hypothesis 3 that time-inconsistent participants decrease their planned retirement age when getting older. We now intend to trace this age effect more closely. Figure 4 shows planned retirement age over different age groups. For most of the age groups, there is little difference between the average planned retirement age of timeconsistent and time-inconsistent participants. ${ }^{12}$ However, after age 50, a gap between the two curves opens up, which is highly significant for the groups of age 51-55 (1.48 years, $p<.01)$ and age $56-60$ (1.71 years, $p<.001)$. When time-inconsistent participants are close to retirement, they are tempted to retire earlier, just as hyperbolic discounting predicts.

For example, Laibson (1997) proposes hyperbolic discounting functions that intersect with exponential discounting 25 years ahead of an outcome (see his figure 1). If we assume that retirement income is an income stream centered around age 75, then 50 would be about the age when hyperbolic discounters start to discount retirement income more strongly than exponential discounters. The difference between the discount functions increases with age, which could explain the widening gap between the groups. While the trend continues in our data for the age group above 60, we omit this group from the graph, as from this age, people start to retire in higher numbers which introduces a selection effect.

We verify the result in a regression framework (see Table 6). We split the sample at median age (40) and run regressions for the resulting age groups separately. To complement the figure, we now employ the number of inconsistent answers as a more precise measure

\footnotetext{
${ }^{12}$ If anything, planned retirement age is higher for time-inconsistent participants when young. This would be consistent with the flatter discount function of hyperbolic discounters for outcomes far away in time. However, the difference is insignificant.
} 
of time preferences. The first two columns show the results for younger participants. The effect of time inconsistency is hardly significant and slightly positive, which means that, when young, time-inconsistent participants plan to retire slightly later than time consistent participants. This turns around for older participants (see columns (3) and (4)), who plan to retire earlier by around four months per inconsistent answer. When we restrict the age range further (to above 50 or 55 years), the impact of time-inconsistent preferences increases in line with Hypothesis 3a. The $\delta$-measure suggested by Oster (2019) is well above one $(>6)$ for all sub-samples, suggesting a low risk of omitted variable bias. ${ }^{13}$

\section{Sophisticated vs. Naïve Hyperbolic Decision Makers}

We already introduced the important distinction between sophisticated and naïve hyperbolic discounters (Laibson, 1997; Diamond and Köszegi, 2003). Sophisticated hyperbolic discounters are aware of their time preferences and anticipate that they might revise their planned retirement timing in the future. To prevent time inconsistency, they would seek to commit to a late retirement decision when young. However, in the German and most other social security systems, a commitment device allowing for a binding decision is not available. While, in theory, strategic undersaving has been proposed as a commitment device, mandatory contributions to social security provide retirement income sufficient to retire regardless (even if not maintaining prior living standards).

Results so far suggest that early retirement and downward revision of retirement plans are widespread among participants. Either participants are predominantly naïve, or they are sophisticated without access to a commitment device. In the latter case, they would at least try to cushion the consequences of anticipated early retirement by additional retirement provisions. Therefore, we analyze whether time-inconsistent participants buy private pension insurance to compensate for an anticipated reduction in social security benefits due to early

\footnotetext{
${ }^{13}$ There is no established procedure to compute $\delta$ for interaction terms, which is why we do not report a value for Table 5 . However, the nature of the subsample analysis is very similar.
} 
retirement. While there are other means of saving for retirement, private pension insurance uptake provides indicative evidence on Hypothesis 4.

Results in Tables 5 and 6 revealed that owning private pension insurance is negatively related to planned retirement age. The motivation to purchase private pension insurance might thus be to afford earlier retirement. To find out who owns private pension insurance, we regress a pension insurance indicator on time preferences in a linear probability model (see Table 7). As columns (1) and (2) reveal, time-inconsistent participants are less likely to purchase private pension insurance. From a base level of $65 \%$, they are $4.5 \%$-points less likely to do so, or 2\%-points for each time-inconsistent answer. This effect is robust to the inclusion of impatience and further control variables (columns (3) to (5)), and also holds in a logistic regression (see Online Appendix, Table F.2). The result is unlikely to be affected by omitted variable bias $(\delta=9.7)$. As the effect is opposite to what Hypothesis 4 suggests, we interpret it as evidence against $\mathrm{H} 4$.

Participants seem not to be sophisticated in the sense that they anticipate their earlier retirement and provide for it. Instead, the present-biased nature of their time preferences seems to result in a lower propensity for private pension savings. Retiring early without sufficient replacement by other means of savings has severe financial consequences. Not only do retirees incur a deduction from their social security benefits by each month they retire earlier, but they also forgo additional contributions they would be making when retiring later. In Online Appendix B, we provide a calculation of the financial impact of on average 1.75 years of earlier retirement we observe for time-inconsistent participants (actual retirement age, see Table 3). In the German social security system, this would lead to a reduction in retirement benefits of about 10\% (see also Engelhardt, Gruber and Kumar, 2020). 


\section{Evidence from a Representative Household Survey}

\section{A. The SAVE Dataset}

For complementary evidence, we use a representative German household panel (SAVE). The SAVE panel survey has been conducted between 2001 and 2013 by the Munich Center for the Economics of Aging (MEA). It focuses on savings behavior, financial assets, and oldage provision (for a detailed description, see Börsch-Supan et al., 2009). We use the four survey waves of 2008, 2009, 2010, and 2011 in the following analyses. Waves before 2008 are excluded, as in a reform of the German pension system, the full retirement age was raised to 67 in 2007. In line with Behaghel and Blau (2012), we find that participants use the full retirement age as an anchor for their planned retirement age. Therefore, a change of the full retirement age represents a structural break in the data. The wave of 2013 is excluded due to a shorter questionnaire that misses key variables.

The main dependent variables, planned retirement age and actual retirement age, as well as the control variables, are similar to those used in the FAZ experiment. The two data sets are complements, as the SAVE survey provides a more diverse sample of respondents and, due to its panel structure, allows studying changes within person. However, none of the survey waves in the SAVE panel includes an explicit measure for inconsistent time preferences. Instead, we use participants' cigarette smoking habits and their use of bank account overdrafts as proxies.

In the medical and psychological literature, smoking has been frequently related to impulsivity, lack of self-control, and hyperbolic discounting (Bickel, Odum and Madden, 1999; Krishnan-Sarin et al., 2007; Reynolds and Fields, 2012; Stillwell and Tunney, 2012; Daly, Delaney and Baumeister, 2015). The empirical link between hyperbolic discounting and smoking has been mostly confirmed in economics (Kan, 2007; Grignon, 2009; Ida, 2014; Kang and Ikeda, 2014), even though some studies find mixed evidence (Khwajaa, Silverman and Sloan, 2007; Harrison, Lau and Rutström, 2010). Gruber and Köszegi (2004) formulate a theoretical 
model of inconsistent time preferences and smoking behavior, which they believe describes smoking decisions better than an exponential model.

Within this literature, several studies explicitly relate smoking behavior to monetary measures of time preferences similar to the one used in the FAZ experiment. Bickel, Odum and Madden (1999) find higher discount rates and a better fit of the hyperbolic discounting model for smokers. Stillwell and Tunney (2012) likewise report steeper discounting by smokers within a hyperbolic model. Grignon (2009) shows that present-biased respondents find it harder to quit smoking, while Ida (2014) and Kang and Ikeda (2014) find that both present bias and impatience predict smoking behavior. Harrison, Lau and Rutström (2010) find only a slightly higher prevalence of time inconsistent preferences among smokers, which is not statistically significant.

Smoking behavior has been used before as a proxy for inconsistent time preferences in the financial domain. Most closely related to our study, Finke and Huston (2013) find a negative relation between smoking and the perceived importance of saving for retirement. Uhr, Meyer and Hackethal (2021) report that smokers among brokerage clients are prone to excessive trading behavior. Smokers also show a higher demand for savings plans (presumably as a commitment device), but they are less likely to maintain the savings plan over longer time horizons. Based on the strong link between smoking and inconsistent time preferences and its availability in the SAVE survey, we opt to use it as a time preference proxy.

Smoking as a time inconsistency proxy has the disadvantage that it might influence retirement timing due to health effects. Non-smokers are on average in better health than smokers. We thus have to control for health to overcome omitted variable bias. In the analysis, we include three variables measuring the health status of SAVE participants: 1) self-assessed health status on a five-point scale; 2) satisfaction with the current health status on a tenpoint scale; 3) whether a participant currently suffers (or has suffered) from a prolonged illness. Subjective reports of health have been shown to have important effects on retirement timing (McGarry, 2004). We find that the elicited variables are moderately correlated in the 
expected direction, which suggests that they cover different but related aspects of subjective health.

As an alternative to smoking behavior, we consider the use of bank account overdrafts as a time preference proxy. Unlike in the U.S. and other countries, where credit cards are used to obtain a flexible short-term credit line, bank overdrafts fulfill this function in Germany. ${ }^{14}$ Almost every adult with a bank account has access to a credit line for overdrafts. Features of overdrafts that resemble credit cards are high interest rates relative to other means of consumer credit and the absence of a fixed repayment scheme. Like credit card debt, overdrafts can be carried over for many months or even years.

Regular use of credit card debt or overdrafts might indicate a desire for immediate gratification keeping people from waiting until the next paycheck. Meier and Sprenger (2010) find that present bias correlates with the existence and amount of credit card debt. Shui and Ausubel (2005) show that hyperbolic discounting can explain credit card borrowing behavior in a large field experiment. More recently, Kuchler and Pagel (2021) show that present bias adversely affects the pay-down of credit cards. While overdrafts are less studied, there is evidence that present bias (but not impatience) increases the frequency of overdraft usage (Becker, Jaroszek and Weber, 2017). Frequent users are also more willing to use expensive overdrafts to finance regular consumption.

In the SAVE survey, overdraft usage is measured on a scale from one ("never") to four ("more than six times per year or permanently"). In addition, we use an overdraft indicator that takes a value of one for frequent users ( 3 or 4 on the scale). Table 8 shows summary statistics for the 2010 wave of the SAVE survey. Overdrafts are more frequently used by non-retirees than by retirees, and $32 \%$ of the former can be classified as frequent users. The percentage of smokers is $31 \%$ for non-retirees and $14 \%$ for retirees. We find that smokers use overdrafts more $(2.1)$ than non-smokers $(1.9, \mathrm{p}<.01)$, which suggests that the two timeinconsistency proxies are related. The correlations between the two proxies are $0.08(\mathrm{p}<.01)$

\footnotetext{
${ }^{14}$ Most credit cards issued in Germany work similar to debit cards or charge cards, where the balance is settled in full at the end of each month.
} 
for the 2010 wave and $0.23(\mathrm{p}<.01)$ for the panel. Additional control variables in the SAVE survey include demographics, financial literacy, subjective life expectancy, and whether or not participants own private pension insurance (see Appendix).

\section{B. Comparison of Datasets}

The planned retirement age of SAVE participants is comparable to the FAZ sample, while the actual retirement age is lower. The datasets further strongly differ in average income, education, and the fraction of female participants (see Tables 1 and 8). This reflects the educated, more affluent, and predominantly male readership of the FAZ business section. Further differences arise from the fact that SAVE oversamples older participants and has a much higher fraction of retirees. For illustration, we provide an explicit comparison for income and education in Online Appendix E. We compare the values in the two surveys with official data from the German federal statistical office. As expected for a representative survey, income and education of SAVE participants are very close to the German average. The FAZ sample differs remarkably as net income is almost double the German average and university education more than three times more common.

While there is little reason to believe that inconsistencies observed for educated and affluent people will be absent in a more representative sample, the SAVE results provide evidence against selection effects. In addition, we replicate the prior analyses for the FAZ sample for less educated or lower-income participants. The results displayed in Online Appendix E show that effect sizes are often larger in these subsamples (even though sometimes insignificant due to a much smaller sample size). This is consistent with the common view that more sophisticated people are less susceptible to bias. For example, Stango and Zinman (2019) show for a number of behavioral biases, including time inconsistency, that biasedness decreases with education and income even though there is large heterogeneity. 


\section{SAVE: Results for Actual Retirement Age}

We first repeat the analysis of actual retirement age with data from the SAVE 2010 survey. We use the cross-section in this analysis and will later zoom in on those who retire during the panel. In the 2010 wave, 907 participants indicate that they are already retired. We proxy for time preferences by smoking habits and overdraft usage. As smoking has negative effects on health, we include variables on participants' health status in the analysis. A second concern is the selective mortality of smokers. Studies that analyze the effect of regular cigarette smoking find that it, on average, reduces life expectancy by ten years (Doll et al., 2004; Sakata et al., 2012; Jha et al., 2013). Consequently, the health status of the surviving smokers in the data set is biased upward. However, observing more healthy smokers is an advantage as we are interested in the component of the smoking variable that is correlated with time preferences, not health. Within the panel, we observe only slightly higher panel attrition for smokers among retirees (see Online Appendix F).

Table 9 presents the results of linear regressions with the actual retirement age as the dependent variable. In column (1), only smoking as a time inconsistency proxy is included in the regression. In column (2), control variables on participants' health status are added. Column (3) includes health controls, demographics, and other control variables. In all three specifications, smoking predicts earlier retirement. The average difference in actual retirement age between smokers and non-smokers is about 3.6 years (column (1)). Adding health variables (column (2)) does not change the magnitude and significance of the effect. In the full model with all controls (column (3)), the coefficient for the smoking indicator is somewhat reduced but still negative and strongly significant. As we control for health, life expectancy, and further personal characteristics, we attribute the remaining difference between smokers and non-smokers mostly to time preferences. In a robustness test, we find similar coefficients

for former smokers who are identified by using prior waves of the SAVE panel (see Online Appendix F). 
In columns (4) to (6), we repeat the analysis for overdraft usage as a time preference proxy. We find that frequent overdraft usage is negatively related to retirement age in all specifications. Economically, a shift of two notches on the four-point scale has an effect about equal in magnitude to smoking. For overdraft usage, it is most important to control for variables such as income and financial literacy. As the results in column (6) show, the coefficient for overdrafts remains relatively stable when including controls. We conclude that inconsistent time preferences proxied by smoking habits or overdraft usage contribute to earlier retirement (in line with Hypothesis 1).

Besides the time inconsistency proxies, poor health is predictive of early retirement. Selfassessed health status is associated with a 1.3-1.5 year reduction in retirement age for a one-point decrease on the five-point scale. This variable seems to subsume the other health variables as they remain insignificant. In the full model (columns (3) and (6)), gender, income, and education show the same effects as for the FAZ sample (see Table 4). In addition, life expectancy and owning private pension insurance obtain statistical significance. Quite intuitively, participants with shorter life expectancy retire earlier, while those who own private pension insurance retire earlier. For smoking behavior, $\delta=2.8$ for the regression with full controls, and for overdraft usage $\delta=4.2$.

To exploit the panel structure of the data, we next concentrate on participants who retire during the panel $(\mathrm{n}=123)$. We compare their age in the year they retire with the planned retirement age they expressed in the last survey wave prior to retirement. This allows us to identify individuals who retired earlier than planned. It turns out that such time inconsistencies are quite frequent, as $40 \%$ of participants retire earlier than they indicated just a year prior. Figure 5 shows a strong correlation between retiring earlier than planned and both smoking behavior and overdraft usage. While non-smokers retire earlier in only $30 \%$ of cases, the fraction for smokers is twice as high. For frequent overdraft users, the incidence is also much higher than for non-frequent users. We confirm this relationship in regressions with all controls (see Online Appendix F). 
The within-person results confirm the existence of time inconsistencies in retirement timing decisions. Hyperbolic discounters not only retire earlier (in both FAZ data and SAVE data), they are also more likely to disregard their own plan. The short time period of just a year between stated preference and decision suggests that, in line with theory, preference shifts happen in the final years prior to retirement. We will revisit this issue in the analysis of revisions in the planned retirement age below.

\section{SAVE: Results for Planned Retirement Age}

In a second test, we track the planned retirement age of individuals in the SAVE panel. The analysis is restricted to 1,653 non-retirees who participate at least twice in the SAVE survey from 2008-2011. We hereby compare similar samples across time and obtain within-person changes in planned retirement age. We run panel regressions with participant fixed effects and planned retirement age as the dependent variable. A survey wave variable is included to show the effect of progressing time on planned retirement age. It takes a value of 0 for the year 2008 and values of 1 to 3 for subsequent years. The fixed effects absorb all static controls, which leaves us with subjective health measures that change over time and may have a profound effect on planned retirement timing. The SAVE data are multiply imputed, and all five imputations are used. Coefficients and standard errors for imputed data are calculated according to Rubin (1987).

Table 10 presents in Panel A results for smoking behavior and in Panel B results for overdraft usage. Column 1 shows the full sample in both panels. It reveals that survey participants reduce their planned retirement age each year by about 0.1 years. After ten years, this would result in one year earlier planned retirement. Unlike for the FAZ sample, this is a within-subject effect as we track participants over time. To classify participants, we identify smokers and overdraft users as those who smoke or use overdrafts frequently in at least one survey wave. ${ }^{15}$ As before, we expect time-inconsistent participants to revise their

\footnotetext{
${ }^{15}$ As behavior is very stable, fractions are only slightly higher than the cross-sectional summary statistics displayed in Table 8. The aim is to consistently group people as either time inconsistent or consistent. We
} 
planned retirement age downward, while time-consistent participants do not. We thus split the sample by the two time inconsistency proxies.

Columns (2)-(4) of Panel A show results for smokers, who reduce their planned retirement age more strongly by about 0.2 years each year. Hyperbolic discounting predicts this effect to be concentrated among people approaching retirement. We thus further restrict the sample to participants over age 40 and over age 50 . The effect becomes stronger the closer participants are to retirement and amounts to 0.26 years each year for those over 40 and even 0.32 years for those over 50. In contrast, it remains insignificant for participants under 40 (not tabulated). Even the relatively short panel thus illustrates how a difference in actual retirement age of more than three years (documented in Table 9) can arise, as there is no similar reduction for non-smokers (see columns (5)-(7)). In the panel, the declining health of smokers does not explain the effect. Overdraft usage in Panel B exhibits qualitatively similar but less pronounced results. Frequent overdraft users reduce their planned retirement age more strongly than non-users, but not significantly so.

We finally reexamine the take-up of private pension insurance to study whether hyperbolic discounters anticipate their earlier than planned retirement. If they were sophisticated, they might seek to make up for expected losses in retirement benefits. Table F.4 in the Online Appendix shows results of a regression of private pension ownership on time preference proxies. We find no or even a negative effect of time inconsistency. We interpret this as a sign of naïvete: Participants do not anticipate earlier than planned retirement, or they are unable to commit to private pension insurance.

\section{Discussion}

Policy interventions in retirement timing mostly target later retirement. This can be justified by keeping social security systems solvent, as they are burdened by increasing life expectancy

obtain similar results when using wave-by-wave behavior. However, as the proxies are not available for 2011, the panel would be shorter. 
and low birth rates in many developed countries. The primary lever is adjustments to the social security rules, such as shifts in early or full retirement age or adjustments to the social security formula. French (2005) and French and Jones (2012) analyze the effects of such policy changes using a structural approach under the assumption of time-consistent individuals. General reductions in retirement benefits or shifts in retirement age are in their models less effective than the removal of disincentives to work such as earnings tests or actuarially unfair adjustments for early or late claiming.

The effects of changes to the social security rules hereby depend much on the forwardlooking behavior of individuals (French, 2005). As structural retirement models almost exclusively rely on exponential time preferences, consistent behavior over time is the norm. However, we find evidence that time-inconsistent individuals are naïve about their time preferences, which means that they have limited capacity to offset changes to the rules by adjusting their consumption behavior. Even sophisticated hyperbolic discounters need commitment devices to implement a forward-looking plan that considers their future behavior. When Gustman and Steinmeier (2012) introduce hyperbolic discounting to structural retirement models, they model sophisticated individuals with access to commitment devices. Individuals are able to implement a consistent intertemporal consumption plan, which is why they find little differences in response to policy interventions. In addition, they model leisure preferences independently of time preferences, which are thus not subject to present bias. $^{16}$

Under more realistic assumptions of partly naïve hyperbolic discounters and limited commitment devices, we expect rule changes to have the strongest effect when they impact incentives around the point of retirement rather than in later years. For example, the German social security system has a benefit reduction of only $3.6 \%$ p.a. for claiming early, which is less than what would be actuarially fair (Blundell, French and Tetlow, 2016). A stronger penalty would disproportionally affect time-inconsistent individuals, as they tend to retire

\footnotetext{
${ }^{16}$ This is in contrast to the theoretical literature, which mostly models work as an effort cost that reduces current consumption utility (Diamond and Köszegi, 2003).
} 
earlier and weigh an immediate consumption loss more heavily. Indeed, Gustman and Steinmeier (2012) find a stronger response of hyperbolic discounters to steeper retirement credits. As they model the retirement credit for retiring after the full retirement age, it seems likely that differences would be even more pronounced for early retirement penalties.

An interesting case is earnings tests, which are a strong disincentive to work after claiming retirement benefits (French, 2005). ${ }^{17}$ Forward-looking individuals respond to the removal of the earnings test by working longer, whereby exponential discounters react more strongly (Gustman and Steinmeier, 2012). However, time-inconsistent retirees face another consequence of earnings tests, which is that they make it more costly to reverse a premature entry into retirement. We find that time-inconsistent retirees often experience retirement regret that could be reduced by removing barriers for reentry. More generally, the possibility to reverse claiming decisions would be an interesting but rarely discussed policy intervention.

Although we have just described a case in which hyperbolic discounters would benefit from greater flexibility to reverse previous decisions that they no longer consider optimal, flexibility can also be harmful. Börsch-Supan et al. (2018) illustrate this for the case of gradual work hour reduction that is equally likely to delay full retirement as it is to induce earlier part-time retirement. Sophisticated hyperbolic discounters have a natural demand for commitment devices that tie their hands, for example, by setting an early retirement age (ERA) before which it is not possible to draw retirement benefits. In structural models, the effect of shifting the ERA is modest (French, 2005; Gustman and Steinmeier, 2005), but in reality such shifts have relatively large effects (Manoli and Weber, 2016). What the models do not capture are social norms on appropriate retirement ages, a reluctance to spend from savings to finance early retirement, and loss aversion relative to reference ages (Behaghel and Blau, 2012; Merkle, Schreiber and Weber, 2017). Already Thaler and Shefrin (1981) discuss that norms are useful to enhance self-control. Therefore, setting a later early retirement age works as a commitment device even if liquidity allows for retirement before the ERA.

\footnotetext{
${ }^{17}$ An earnings test entails the reduction or taxation of retirement benefits when receiving labor income.
} 
Dealing with time-inconsistent individuals might call for more innovative policy interventions such as refined commitment devices. An example is allowing contributors to lock in a specific retirement age ex-ante. Changes would then only be possible in case of unexpected shocks (e.g., severe health decline or job loss). Bond and Sigurdsson (2017) suggest contracts that combine commitment with the flexibility to react to shocks by exploiting preference reversals in hyperbolic preferences. Yu (2021) proposes a solution that involves menus of different retirement consumption paths depending on claiming age. Some off-paths exist only to motivate effort in the employment phase but are theoretically never chosen when retiring. It is difficult to imagine such policies in reality, as they increase complexity, and almost surely some retirees will be locked in inferior options due to decision mistakes. As a simpler alternative, a waiting period of several months between claiming and receiving benefits would protect both naïve and sophisticated hyperbolic discounters from the most immediate impact of present bias. ${ }^{18}$

\section{Conclusion}

In an experiment on choices within the social security system, we relate the decision of when to retire to participants' time preferences. In cooperation with the FAZ, a large and wellcirculated German newspaper, we recruit more than 2,000 participants. They answer a set of questions on the preferred time to receive a tax refund, which allows us to measure their time preferences. We use this measure to analyze the effect of inconsistent (hyperbolic) time preferences on participants' actual and planned retirement age. We find that participants with hyperbolic time preferences are more likely to show inconsistent retirement planning. Time-inconsistent participants advance their planned retirement as they age. The temptation of early retirement seems to increase further when retirement approaches. From age fifty, they reduce their planned retirement age relative to the group of time-consistent participants.

\footnotetext{
${ }^{18}$ Time consistent contributors would be (largely) unaffected by these changes as their retirement plans are stable over time. A similar solution has been advocated in a blog by Beeminder (https://blog.beeminder.com/flexbind), a self-tracking app to reach personal goals.
} 
While plans might not reflect future behavior, the influence of time preferences can be confirmed for the actual retirement age of participants who are already retired. On average, time-inconsistent participants retire 1.75 years earlier than time consistent participants. Earlier retirement has severe financial consequences for the remaining lifetime as it results in a permanent decrease in monthly retirement benefits (of about 10\% in the German social security system). In addition, time inconsistent participants are more likely to regret their retirement decision. A third of retired participants who are classified as time inconsistent indicate that they would retire later if they could make the retirement entry decision again. This suggests that they retire rather spontaneously and not in line with their prior and later preferences. 


\section{Appendix: Variable Definitions}

\begin{tabular}{|c|c|}
\hline \multicolumn{2}{|r|}{ FAZ Survey } \\
\hline Variable & Description \\
\hline Planned Retirement Age & $\begin{array}{l}\text { Age in years non-retired participants plan to retire ("At } \\
\text { what age do you plan to retire?"). Non-retirees only. }\end{array}$ \\
\hline Actual Retirement Age & $\begin{array}{l}\text { Age in years when retired participants did retire ( "At } \\
\text { what age did you retire?"). Retirees only. }\end{array}$ \\
\hline Full Retirement Age & $\begin{array}{l}\text { Full retirement age according to the German social se- } \\
\text { curity system based on the birth year of participants. }\end{array}$ \\
\hline Retirement Regret & $\begin{array}{l}\text { Indicator that equals one if participants felt they retired } \\
\text { too early ("If you were to retire again, would you retire } \\
\text { earlier, later, or at the same age?"). Retirees only. }\end{array}$ \\
\hline Inconsistency Indicator & $\begin{array}{l}\text { Refers to the time preference question as displayed in } \\
\text { Figure } 1 \text {. Indicator equals one if a participant makes } \\
\text { at least one time-inconsistent choice in the direction of } \\
\text { hyperbolic discounting. }\end{array}$ \\
\hline Number Inconsistent & Refers to the time preference question as displayed in \\
\hline Answers & $\begin{array}{l}\text { Figure } 1 . \text { Count of the number of inconsistent choices in } \\
\text { the direction of hyperbolic discounting }(0-3) \text {. }\end{array}$ \\
\hline Impatience & $\begin{array}{l}\text { Agreement on a seven-point Likert scale (1-7) to the } \\
\text { statement "I am an impatient person". }\end{array}$ \\
\hline Age & Current age of participants in years. \\
\hline Gender & Indicator that equals one if a participant is male. \\
\hline Income & Self-reported monthly net income. Non-retirees only. \\
\hline Retirement Benefits & $\begin{array}{l}\text { Retirement income from social and private insurance. } \\
\text { Retirees only. }\end{array}$ \\
\hline Satisfaction with Benefits & $\begin{array}{l}\text { Agreement on a seven-point Likert scale }(1-7) \text { to the } \\
\text { statement "I am satisfied with my monthly retirement } \\
\text { benefits". }\end{array}$ \\
\hline Number of Children & Number of participant's children. \\
\hline Education & $\begin{array}{l}\text { Variable that takes a value of } 2 \text { for a university degree } \\
\text { or higher, a value of } 1 \text { for a high school degree (German } \\
\text { Abitur), and a value of } 0 \text { for a lower or no degree. }\end{array}$ \\
\hline Married & Indicator that equals one if a participant is married. \\
\hline Risk Aversion & $\begin{array}{l}\text { Agreement on a seven-point Likert scale (1-7) to the } \\
\text { statement "I am a risk-averse person". }\end{array}$ \\
\hline Loss Aversion & $\begin{array}{l}\text { Agreement on a seven-point Likert scale (1-7) to the } \\
\text { statement "I am very afraid of losses". }\end{array}$ \\
\hline Financial Literacy & $\begin{array}{l}\text { Number of correct responses to six financial literacy } \\
\text { questions (see Online Appendix A). }\end{array}$ \\
\hline Subjective Life Expectancy & Self-reported life expectancy in years of age. \\
\hline Private Pension Insurance & Indicator if participant owns private pension insurance. \\
\hline
\end{tabular}




\begin{tabular}{|c|c|}
\hline \multicolumn{2}{|r|}{ SAVE Survey } \\
\hline Variable & Description \\
\hline Planned Retirement Age & $\begin{array}{l}\text { Age in years non-retired participants plan to retire ( "At } \\
\text { what age do you plan to retire?"). Non-retirees only. }\end{array}$ \\
\hline Actual Retirement Age & $\begin{array}{l}\text { Age in years when retired participants did retire ("At } \\
\text { what year did you enter retirement?"). Retirees only. }\end{array}$ \\
\hline Smoker & $\begin{array}{l}\text { Indicator that equals one if a participant responds yes } \\
\text { to the question "Do you smoke regularly?" at least once } \\
\text { in the used rounds of the panel. }\end{array}$ \\
\hline Overdraft & $\begin{array}{l}\text { Overdraft measures the self-reported usage of the over- } \\
\text { draft option provided by the participant's bank. It } \\
\text { ranges from } 1 \text { (never use overdraft) to } 4 \text { (more than } 6 \\
\text { times per year). }\end{array}$ \\
\hline Overdraft Indicator & $\begin{array}{l}\text { Indicator that equals one if participants use the over- } \\
\text { draft option frequently (overdraft } \geq 2 \text { ) at least once in } \\
\text { the used rounds of the panel. }\end{array}$ \\
\hline Age & Current age of participants in years. \\
\hline Gender & Indicator that equals one if a participant is male. \\
\hline Income & Self-reported monthly net income. \\
\hline Number of Children & Number of participant's children. \\
\hline Education & $\begin{array}{l}\text { Variable that takes a value of } 2 \text { for a university degree } \\
\text { or higher, a value of } 1 \text { for a high school degree (German } \\
\text { Abitur), and a value of } 0 \text { for a lower or no degree. }\end{array}$ \\
\hline Married & Indicator that equals one if a participant is married. \\
\hline Financial Literacy & $\begin{array}{l}\text { Number of correct responses to nine financial literacy } \\
\text { questions (see Online Appendix B). }\end{array}$ \\
\hline Subjective Life Expectancy & Self-reported life expectancy in years of age. \\
\hline Private Pension Insurance & $\begin{array}{l}\text { Indicator that equals one if a participant owns private } \\
\text { pension insurance. }\end{array}$ \\
\hline Health Status & $\begin{array}{l}\text { Self-assessed health status on a five-point scale (from } \\
\text { very good }(=5) \text { to very bad }(=1) \text { ). }\end{array}$ \\
\hline Satisfaction with Health & $\begin{array}{l}\text { self-reported satisfaction with own health on a ten-point } \\
\text { scale (from completely satisfied }(=10) \text { to not at all sat- } \\
\text { isfied }(=0)) \text {. }\end{array}$ \\
\hline Prolonged Illness & $\begin{array}{l}\text { Indicator that takes the value of one if a participant } \\
\text { reports to have prolonged health problems, illnesses, or } \\
\text { disabilities. }\end{array}$ \\
\hline
\end{tabular}




\section{References}

Ahlbrecht, Martin, and Martin Weber. 1997. "An Empirical Study on Intertemporal Decision Making Under Risk." Management Science, 43(6): 813-826.

Ainslie, George, and Varda Haendel. 1983. "The Motives of the Will." In Etiologic Aspects of Alcohol and Drug Abuse, ed. E. Gottheil et al., 119-140. Springfield, IL: Charles C. Thomas.

Andersen, Steffen, Glenn Harrison, Morten Lau, and Elisabet Rutström. 2008. "Eliciting Risk and Time Preferences." Econometrica, 76(3): 583-618.

Ashraf, Nava, Dean Karlan, and Wesley Yin. 2006. "Tying Odysseus to the Mast: Evidence From a Commitment Savings Product in the Philippines." The Quarterly Journal of Economics, 121(2): 635-672.

Bazzoli, Gloria. 1985. "The Early Retirement Decision: New Empirical Evidence on the Influence of Health." Journal of Human Resources, 20(2): 214-234.

Becker, David, Lena Jaroszek, and Martin Weber. 2017. "Borrower Heterogeneity and the (Ir)Rational Demand for Short-Term Credit." Working Paper.

Beehr, Terry, and Misty Bennett. 2015. "Working After Retirement: Features of Bridge Employment and Research Directions." Work, Aging and Retirement, 1(1): 1-17.

Behaghel, Luc, and David Blau. 2012. "Framing Social Security Reform: Behavioral Responses to Changes in the Full Retirement Age." American Economic Journal: Economic Policy, 4(4): 4167.

Benartzi, Shlomo, and Richard Thaler. 2007. "Heuristics and Biases in Retirement Savings Behavior." Journal of Economic Perspectives, 21(3): 81-104.

Benartzi, Shlomo, and Richard Thaler. 2013. "Behavioral Economics and the Retirement Savings Crisis." Science, 339(6124): 1152-1153.

Bickel, Warren, Amy Odum, and Gregory Madden. 1999. "Impulsivity and Cigarette Smoking: Delay Discounting in Current, Never, and Ex-smokers." Psychopharmacology, 146(4): 447-454.

Bidewell, John, Barbara Griffin, and Beryl Hesketh. 2006. "Timing of Retirement: Including a Delay Discounting Perspective in Retirement Models." Journal of Vocational Behavior, 68(2): 368-387.

Blundell, Richard, Eric French, and Gemma Tetlow. 2016. "Retirement Incentives and Labor Supply." In Handbook of the Economics of Population Aging Vol. 1, ed. J. Piggott and A. Woodland, 457-566. North-Holland: Elsevier.

Bond, Philip, and Gustav Sigurdsson. 2017. "Commitment Contracts." The Review of Economic Studies, 85(1): 194-222.

Börsch-Supan, Axel, Michela Coppola, Lothar Essig, Angelika Eymann, and Daniel Schunk. 2009. "The German SAVE Study Design and Results." MEA Working Paper.

Börsch-Supan, Axel, Tabea Bucher-Koenen, Vesile Kutlu-Koc, and Nicolas Goll. 2018. "Dangerous Flexibility - Retirement Reforms Reconsidered." Economic Policy, 33(94): 315-355. 
Brown, Jeffrey, Arie Kapteyn, and Olivia Mitchell. 2013. "Framing and Claiming: How InformationFraming Affects Expected Social Security Claiming Behavior." The Journal of Risk and Insurance, 83(1): 139-162.

Choi, James, David Laibson, Brigitte Madrian, and Andrew Metrick. 2002. "Defined Contribution Pensions: Plan Rules, Participant Choices, and the Path of Least Resistance." Tax Policy and the Economy, 16: 67-113.

Cohen, Jonathan, Keith Ericson, David Laibson, and John White. 2020. "Measuring Time Preferences." Journal of Economic Literature, 58(2): 299-347.

Coile, Courtney, Peter Diamond, Jonathan Gruber, and Alain Jousten. 2002. "Delays in Claiming Social Security Benefits." Journal of Public Economics, 84(3): 357-385.

Coller, Maribeth, and Melonie Williams. 1999. "Eliciting Individual Discount Rates." Experimental Economics, 2(2): 107-127.

Daly, Michael, Liam Delaney, and Roy Baumeister. 2015. "Self-control, Future Orientation, Smoking, and the Impact of Dutch Tobacco Control Measures." Addictive Behaviors Reports, 1: 89-96.

DellaVigna, Stefano, and Ulrike Malmendier. 2006. "Paying Not to Go to the Gym." The American Economic Review, 96(3): 694-719.

DePreter, Hanne, Dorien Van Looy, and Dimitri Mortelmans. 2015. "Retirement Timing of DualEarner Couples in 11 European Countries? A Comparison of Cox and Shared Frailty Models." Journal of Family and Economic Issues, 36(3): 396-407.

Diamond, Peter, and Botond Köszegi. 2003. "Quasi-hyperbolic Discounting and Retirement." Journal of Public Economics, 87(9-10): 1839-1872.

Doll, Richard, Richard Peto, Jillian Boreham, and Isabelle Sutherland. 2004. "Mortality in Relation to Smoking: 50 Years' Observations on Male British Doctors." BMJ, 328(7455): 1519-1528.

Earl, Catherine, and Philip Taylor. 2015. "Is Workplace Flexibility Good Policy? Evaluating the Efficacy of Age Management Strategies for Older Women Workers." Work, Aging and Retirement, 1(2): 214-226.

Engelhardt, Gary, Jonathan Gruber, and Anil Kumar. 2020. "Early Social Security Claiming and Old-Age Poverty: Evidence from the Introduction of the Social Security Early Eligibility Age." Journal of Human Resources, forthcoming.

European Commission. 2012. "An Agenda for Adequate, Safe and Sustainable Pensions." White Paper.

Falk, Armin, Anke Becker, Thomas Dohmen, David Huffman, and Uwe Sunde. 2016. "The Preference Survey Module: A Validated Instrument for Measuring Risk, Time, and Social Preferences." IZA Discussion Paper No. 9674.

Fetherstonhaugh, David, and Lee Ross. 1999. "Framing Effects and Income Flow Preferences in Decisions about Social Security." In Behavioral Dimensions of Retirement Economics, ed. H. Aaron. Washington DC: Brookings Institution Press and Russell Sage Foundation. 
Finch, Naomi. 2014. "Why Are Women More Likely Than Men to Extend Paid Work? The Impact of Work-Family Life History." European Journal of Ageing, 11(1): 31-39.

Findley, T. Scott, and Frank N. Caliendo. 2015. "Time Inconsistency and Retirement Choice." Economics Letters, 129: 4-8.

Finke, Michael S., and Sandra J. Huston. 2013. "Time Preference and the Importance of Saving for Retirement." Journal of Economic Behavior \& Organization, 89: 23-34.

Fisher, Gwenith, Dorey Chaffee, and Amanda Sonnega. 2016. "Retirement Timing: A Review and Recommendations for Future Research." Work, Aging and Retirement, 2(2): 230-261.

Frederick, Shane, George Loewenstein, and Ted O'Donoghue. 2002. "Time Discounting and Time Preference: A Critical Review." The Journal of Economic Literature, 40(2): 351-401.

French, Eric. 2005. "The Effects of Health, Wealth, and Wages on Labour Supply and Retirement Behaviour." The Review of Economic Studies, 72(2): 395-427.

French, Eric, and John Jones. 2012. "Public Pensions and Labor Supply over the Life Cycle." International Tax and Public Finance, 19(2): 268-287.

Goda, Gopi, Matthew Levy, Colleen Manchester, Aaron Sojourner, and Joshua Tasoff. 2019. "Predicting Retirement Savings Using Survey Measures of Exponential-Growth Bias and Present Bias." Economic Inquiry, 57(3): 1636-1658.

Green, Leonard, Nathanael Fristoe, and Joel Myerson. 1994. "Temporal Discounting and Preference Reversals in Choice between Delayed Outcomes." Psychonomic Bulletin and Review, 1(3): 383389.

Griffin, Barbara, Beryl Hesketh, and Vanessa Loh. 2012. "The Influence of Subjective Life Expectancy on Retirement Transition and Planning: A Longitudinal Study." Journal of Vocational Behavior, 81(2): 129-137.

Grignon, Michel. 2009. "An Empirical Investigation of Heterogeneity in Time Preferences and Smoking Behaviors." The Journal of Socio-Economics, 38(5): 739-751.

Gruber, Jonathan, and Botond Köszegi. 2004. "Tax Incidence When Individuals are Timeinconsistent: The Case of Cigarette Excise Taxes." Journal of Public Economics, 88(9): 19591987.

Gruber, Jonathan, and David Wise. 2004. Social Security Programs and Retirement around the World: Micro-Estimation. Chicago, IL: University of Chicago Press.

Gustman, Alan, and Thomas Steinmeier. 2000. "Retirement in Dual-Career Families: A Structural Model." Journal of Labor Economics, 18(3): 503-545.

Gustman, Alan, and Thomas Steinmeier. 2005. "The Social Security Early Entitlement Age in a Structural Model of Retirement and Wealth." Journal of Public Economics, 89(2): 441-463.

Gustman, Alan, and Thomas Steinmeier. 2012. "Policy Effects in Hyperbolic vs. Exponential Models of Consumption and Retirement." Journal of Public Economics, 96(5): 465-473. 
Halevy, Yoram. 2015. "Time Consistency: Stationarity and Time Invariance." Econometrica, 83(1): 335-352.

Hank, Karsten. 2004. "Effects of Early Life Family Events on Women's Late Life Labour Market Behaviour: An Analysis of the Relationship between Childbearing and Retirement in Western Germany." European Sociological Review, 20(3): 189-198.

Harrison, Glenn, Morten Lau, and Elisabet Rutström. 2010. "Individual Discount Rates and Smoking: Evidence from a Field Experiment in Denmark." Journal of Health Economics, 29(5): 708717.

Harrison, Glenn, Morten Lau, and Melonie Williams. 2002. "Estimating Individual Discount Rates in Denmark: A Field Experiment." American Economic Review, 92(5): 1606-1617.

Hayashi, Takashi. 2003. "Quasi-stationary Cardinal Utility and Present Bias." Journal of Economic Theory, 112(2): 343-352.

Heimer, Rawley, Kristian Myrseth, and Raphael Schoenle. 2019. "YOLO: Mortality Beliefs and Household Finance Puzzles." The Journal of Finance, 6(74): 2957-2996.

Helman, Ruth, Craig Copeland, and Jack VanDerhei. 2008. "EBRI 2008 Recent Retirees Survey: Report of Findings." EBRI Issue Brief 319, 1-22.

Ida, Takanori. 2014. "A Quasi-hyperbolic Discounting Approach to Smoking Behavior." Health Economics Review, 4(1): 1-11.

Jha, Prabhat, Chinthanie Ramasundarahettige, Victoria Landsman, Brian Rostron, Michael Thun, Robert Anderson, Tim McAfee, and Richard Peto. 2013. "21st-Century Hazards of Smoking and Benefits of Cessation in the United States." The New England Journal of Medicine, 368: 341-350.

Kan, Kamhon. 2007. "Cigarette Smoking and Self-Control." Journal of Health Economics, 26(1): 61-81.

Kang, Myong-Il, and Shinsuke Ikeda. 2014. "Time Discounting and Smoking Behavior: Evidence from a Panel Survey." Health Economics, 23(12): 1443-1464.

Khwajaa, Ahmed, Dan Silverman, and Frank Sloan. 2007. "Time Preference, Time Discounting, and Smoking Decisions." Journal of Health Economics, 26(5): 927-949.

Kim, Seongsu, and Daniel Feldman. 1998. "Healthy, Wealthy, or Wise: Predicting Actual Acceptances of Early Retirement Incentives at Three Points in Time." Personnel Psychology, 51(3): 623-642.

Kirby, Kris. 2009. "One-year Temporal Stability of Delay-discount Rates." Psychonomic Bulletin \& Review, 16(3): 457-462.

Kirby, Kris, and Richard Herrnstein. 1995. "Preference Reversals Due to Myopic Discounting of Delayed Reward." Psychological Science, 6(2): 83-89.

Knoll, Melissa. 2011. "Behavioral and Psychological Aspects of the Retirement Decision." Social Security Bulletin, 71(4): 15-32. 
Krishnan-Sarin, Suchitra, Brady Reynolds, Amy Duhig, Anne Smith, Thomas Liss, Amanda McFetridge, Dana Cavallo, Kathleen Carroll, and Marc Potenza. 2007. "Behavioral Impulsivity Predicts Treatment Outcome in a Smoking Cessation Program for Adolescent Smokers." Drug and Alcohol Dependence, 88(1): 79-82.

Kuchler, Theresa, and Michaela Pagel. 2021. "Sticking to Your Plan: The Role of Present Bias for Credit Card Paydown." Journal of Financial Economics, 139(2): 359-388.

Laibson, David. 1997. "Golden Eggs and Hyperbolic Discounting." The Quarterly Journal of Economics, 112(2): 443-478.

Laibson, David, Andrea Repetto, and Jermeny Tobacman. 1998. "Self-Control and Saving for Retirement." Brookings Papers on Economic Activity, 1998(1): 91-196.

Li, Xiaoyan, Michael Hurd, and David Loughran. 2008. "The Characteristics of Social Security Beneficiaries Who Claim at the Early Entitlement Age." Public Policy Institute Working Paper.

Loewenstein, George, and Drazen Prelec. 1992. "Anomalies in Intertemporal Choice: Evidence and an Interpretation." The Quarterly Journal of Economics, 107(2): 573-597.

Lynch, John, and Gal Zauberman. 2006. "When Do You Want It? Time, Decisions, and Public Policy." Journal of Public Policy and Marketing, 25(1): 67-78.

Madero-Cabib, Ignacio, Jacques-Antoine Gauthier, and Jean-Marie Le Goff. 2015. "The Influence of Interlocked Employment - Family Trajectories on Retirement Timing." Work, Aging and Retirement, 2(1): 38-53.

Manoli, Dayanand, and Andrea Weber. 2016. "The Effects of the Early Retirement Age on Retirement Decisions." NBER Working Paper 22561.

McGarry, Kathleen. 2004. "Health and Retirement: Do Changes in Health Affect Retirement Expectations?" Journal of Human Resources, 39(3): 624-648.

Meier, Stephan, and Charles Sprenger. 2010. "Present-Biased Preferences and Credit Card Borrowing." American Economic Journal: Applied Economics, 2(1): 193-210.

Meier, Stephan, and Charles Sprenger. 2012. "Time Discounting Predicts Creditworthiness." Psychological Science, 23(1): 56-58.

Meier, Stephan, and Charles Sprenger. 2015. "Temporal Stability of Time Preferences." The Review of Economics and Statistics, 97(2): 273-286.

Merkle, Christoph, Philipp Schreiber, and Martin Weber. 2017. "Framing and Retirement Age: The Gap between Willingness-to-Accept and Willingness-to-Pay." Economic Policy, 32(92): 757-809.

Moen, Phyllis, and Sarah Flood. 2013. "Limited Engagements? Women's and Men's Work/Volunteer Time in the Encore Life Course Stage." Social Problems, 60(2): 206-233.

Montiel Olea, Jos Luis, and Tomasz Strzalecki. 2014. "Axiomatization and Measurement of QuasiHyperbolic Discounting." The Quarterly Journal of Economics, 129(3): 1449-1499.

Munnell, Alicia, Robert Triest, and Natalia Jivan. 2004. "How Do Pensions Affect Expected and Actual Retirement Ages?" CRR Working Paper 27. 
Noor, Jawwad. 2009. "Hyperbolic Discounting and the Standard Model: Eliciting Discount Functions." Journal of Economic Theory, 144(5): 2077-2083.

Nosić, Alen, and Martin Weber. 2010. "How Riskily Do I Invest? The Role of Risk Attitudes, Risk Perceptions, and Overconfidence." Decision Analysis, 7(3): 282-301.

O'Donoghue, Ted, and Matthew Rabin. 1999. "Doing It Now or Later." The American Economic Review, 89(1): 103-124.

O'Donoghue, Ted, and Matthew Rabin. 2015. "Present Bias: Lessons Learned and to Be Learned." The American Economic Review, 105(5): 273-279.

OECD. 2017. Pensions at a Glance 201\%: OECD and G20 Indicators. Paris: OECD Publishing.

Oster, Emily. 2019. "Unobservable Selection and Coefficient Stability: Theory and Evidence." Journal of Business \&3 Economic Statistics, 37(2): 187-204.

Phelps, Edmund, and Robert Pollak. 1968. "On Second-Best National Saving and GameEquilibrium Growth." The Review of Economic Studies, 35(2): 185-199.

Read, Daniel. 2005. "Monetary Incentives, What Are They Good for?" Journal of Economic Methodology, 12(2): 265-276.

Read, Daniel, and Barbara van Leeuwen. 1998. "Predicting Hunger: The Effects of Appetite and Delay on Choice." Organizational Behavior and Human Decision Processes, 76(2): 189-205.

Reynolds, Brady, and Sherecce Fields. 2012. "Delay Discounting by Adolescents Experimenting With Cigarette Smoking." Addiction, 107(2): 417-424.

Rohde, Kirsten. 2019. "Measuring Decreasing and Increasing Impatience." Management Science, 65(4): 1455-1947.

Rubin, Donald B. 1987. Multiple Imputation for Nonresponse in Surveys. New York, NY: J. Wiley \& Sons.

Rubinstein, Ariel. 2001. "A Theorist's View of Experiments." European Economic Review, 45(46): $615-628$.

Sakata, Ritsu, Paul McGale, Eric Grant, Kotaro Ozasa, Richard Peto, and Sarah Darby. 2012. "Impact of Smoking on Mortality and Life Expectancy in Japanese Smokers: A Prospective Cohort Study." BMJ, 345: e7093.

Sayman, Serdar, and Ayse Öncüler. 2009. "An Investigation of Time Inconsistency." Management Science, 55(3): 470-482.

Schirle, Tammy. 2008. "Why Have the Labor Force Participation Rates of Older Men Increased since the Mid1990s?" Journal of Labor Economics, 26(4): 549-594.

Schreiber, Philipp, and Martin Weber. 2016. "Time Inconsistent Preferences and the Annuitization Decision." Journal of Economic Behavior $\& 3$ Organization, 129: 37-55.

Shu, Suzanne, John Payne, and Namika Sagara. 2014. "The Psychology of SSA Claiming Decisions: Toward the Understanding and Design of Interventions." Working Paper. 
Shui, Haiyan, and Lawrence Ausubel. 2005. "Time Inconsistency in the Credit Card Market." Working Paper.

Sprenger, Charles. 2015. "Judging Experimental Evidence on Dynamic Inconsistency." The American Economic Review, 105(5): 280-85.

Stango, Victor, and Jonathan Zinman. 2019. "We are All Behavioral, More or Less: Measuring and Using Consumer-level Behavioral Sufficient Statistics." NBER Working Paper 25540.

Stillwell, David, and Richard Tunney. 2012. "Effects of Measurement Methods on the Relationship between Smoking and Delay Reward Discounting." Addiction, 107(5): 1003-1012.

Strotz, Robert. 1955. "Myopia and Inconsistency in Dynamic Utility Maximization." The Review of Economic Studies, 23(3): 165-180.

Sutter, Matthias, Martin Kocher, Daniela Glätzle-Rüetzler, and Stefan Trautmann. 2013. "Impatience and Uncertainty: Experimental Decisions Predict Adolescents' Field Behavior." The American Economic Review, 103(1): 510-531.

Takeuchi, Kan. 2011. "Non-parametric Test of Time Consistency: Present Bias and Future Bias." Games and Economic Behavior, 71(2): 456-478.

Thaler, Richard. 1981. "Some Empirical Evidence on Dynamic Inconsistency." Economics Letters, 8(3): 201-207.

Thaler, Richard, and Hersh Shefrin. 1981. "An Economic Theory of Self-Control." Journal of Political Economy, 89(2): 392-406.

Uhr, Charline, Steffen Meyer, and Andreas Hackethal. 2021. "Smoking hot portfolios? Trading behavior, investment biases, and self-control failure." Journal of Empirical Finance, 63: 73-95.

van Rijn, Rogier, Suzan Robroek, Sandra Brouwer, and Alex Burdorf. 2013. "Influence of Poor Health on Exit from Paid Employment: A Systematic Review." Occupational and Environmental Medicine, 71(4): 295-301.

van Rooij, Maarten, Annamaria Lusardi, and Rob Alessie. 2011. "Financial Literacy and Stock Market Participation." Journal of Financial Economics, 101(2): 449-472.

van Solinge, Hanna, and Kène Henkens. 2010. "Living Longer, Working Longer? The Impact of Subjective Life Expectancy on Retirement Intentions and Behaviour." European Journal of Public Health, 20(1): 47-51.

Wang, Mo, and Kenneth Shultz. 2010. "Employee Retirement: A Review and Recommendations for Future Investigation." Journal of Management, 36(1): 172-206.

Woehrmann, Anne, Corinna Brauner, and Alexandra Michel. 2020. "Working Time Preferences and Early and Late Retirement Intentions." Chronobiology International, 37(9-10): 1283-1286.

Yu, Pei. 2021. "Optimal Retirement Policies with Present-Biased Agents." Journal of the European Economic Association, 19(4): 2085-2130.

Zhang, Lin. 2013. "Saving and Retirement Behavior under Quasi-hyperbolic Discounting." Journal of Economics, 109(1): 57-71. 
Table 1

Detailed summary statistics for time preferences

\begin{tabular}{|c|c|c|c|c|c|c|}
\hline \multirow[t]{2}{*}{ Panel A } & \multicolumn{3}{|c|}{ Retirees } & \multicolumn{3}{|c|}{ Non-Retirees } \\
\hline & sooner & later & $\%$ sooner & sooner & later & $\%$ sooner \\
\hline Immediate tax refund (low interest rate) & 154 & 39 & $80 \%$ & 1,723 & 409 & $81 \%$ \\
\hline Immediate tax refund (medium interest rate) & 112 & 81 & $58 \%$ & 946 & 1,186 & $44 \%$ \\
\hline Immediate tax refund (high interest rate) & 104 & 89 & $54 \%$ & 535 & 1,597 & $25 \%$ \\
\hline Delayed tax refund (low interest rate) & 116 & 77 & $60 \%$ & 1,278 & 854 & $60 \%$ \\
\hline Delayed tax refund (medium interest rate) & 73 & 120 & $38 \%$ & 393 & 1,739 & $18 \%$ \\
\hline Delayed tax refund (high interest rate) & 79 & 114 & $41 \%$ & 157 & 1,975 & $7 \%$ \\
\hline Panel B & \multicolumn{3}{|c|}{ Retirees } & \multicolumn{3}{|c|}{ Non-Retirees } \\
\hline Observations included in analysis & & $\mathrm{n}$ & $\%$ & & $\mathrm{n}$ & $\%$ \\
\hline $\begin{array}{l}\text { Time Consistent } \\
\# \text { inconsistent answers }=0\end{array}$ & & 122 & $63.2 \%$ & & 1257 & $59.0 \%$ \\
\hline Present Biased & & & & & & \\
\hline \# inconsistent answers $=1$ & & 38 & $19.7 \%$ & & 490 & $23.0 \%$ \\
\hline \# inconsistent answers $=2$ & & 13 & $6.7 \%$ & & 185 & $8.7 \%$ \\
\hline \# inconsistent answers $=3$ & & 14 & $7.3 \%$ & & 179 & $8.4 \%$ \\
\hline Total & & 187 & $96.9 \%$ & & 2111 & $99.0 \%$ \\
\hline Observations excluded from analysis & & $\mathrm{n}$ & $\%$ & & $\mathrm{n}$ & $\%$ \\
\hline Future Biased & & 4 & $2.1 \%$ & & 17 & $0.8 \%$ \\
\hline Mixed Biased & & 2 & $1.0 \%$ & & 4 & $0.2 \%$ \\
\hline Total & & 6 & $3.1 \%$ & & 21 & $1.0 \%$ \\
\hline
\end{tabular}

Notes: The table presents detailed summary statistics of the time preference measure used in the survey (see Figure 1). Panel A shows choices of participants (sooner or later tax refund) in each of the six questions separately for the sub-samples of retirees and non-retirees. Panel B specifies time-consistent responses, present-biased responses and other response patterns. 
Table 2

Summary statistics

\begin{tabular}{|c|c|c|c|c|}
\hline & \multicolumn{2}{|c|}{ Retirees $(\mathrm{n}=187)$} & \multicolumn{2}{|c|}{ Non-Retirees $(\mathrm{n}=2,111)$} \\
\hline & Mean & Std. Dev. & Mean & Std. Dev. \\
\hline \multicolumn{5}{|l|}{ A Retirement Timing } \\
\hline Planned Retirement Age & & & 64.97 & 3.81 \\
\hline Actual Retirement Age & 61.54 & 4.64 & & \\
\hline Full Retirement Age & 65.14 & 0.25 & 66.72 & 0.52 \\
\hline Retirement Regret & 0.22 & 0.41 & & \\
\hline \multicolumn{5}{|l|}{ B Time Preferences } \\
\hline Inconsistency Indicator & 0.35 & 0.48 & 0.40 & 0.49 \\
\hline Number Inconsistent Answers [0-3] & 0.57 & 0.92 & 0.66 & 0.95 \\
\hline Impatience $[1-7]$ & 3.85 & 1.77 & 3.88 & 1.62 \\
\hline \multicolumn{5}{|l|}{ C Demographics } \\
\hline Age & 66.66 & 5.70 & 40.10 & 12.10 \\
\hline Gender $[$ male $=1]$ & 0.88 & 0.33 & 0.85 & 0.36 \\
\hline Income & & & $3,411.73$ & $3,125.81$ \\
\hline Retirement Benefits & 3157.41 & 4639.30 & & \\
\hline Satisfaction with Benefits [1-7] & 5.00 & 1.83 & & \\
\hline Number of Children & 1.64 & 1.19 & 0.78 & 1.19 \\
\hline Education $[0-2]$ & 1.44 & 0.78 & 1.61 & 0.62 \\
\hline Married & 0.82 & 0.39 & 0.47 & 0.50 \\
\hline \multicolumn{5}{|l|}{ D Additional Controls } \\
\hline Risk Aversion [1-7] & 4.02 & 1.51 & 3.89 & 1.46 \\
\hline Loss Aversion [1-7] & 4.67 & 1.59 & 4.22 & 1.59 \\
\hline Financial Literacy $[0-6]$ & 3.98 & 0.93 & 4.15 & 1.13 \\
\hline Subjective Life Expectancy & 84.35 & 6.45 & 83.53 & 7.78 \\
\hline Private Pension Insurance & 0.36 & 0.48 & 0.65 & 0.48 \\
\hline
\end{tabular}

Notes: The table shows summary statistics for the FAZ survey, separately for the sub-samples of retired and non-retired participants. Variables are as defined in the Appendix. 
Table 3

Effect of time preferences on actual retirement age

\begin{tabular}{|c|c|c|c|c|c|}
\hline & \multicolumn{5}{|c|}{ Actual Retirement Age } \\
\hline & (1) & $(2)$ & $(3)$ & (4) & (5) \\
\hline Inconsistency Indicator & $\begin{array}{c}-1.758 \\
(0.80)^{* *}\end{array}$ & & & & \\
\hline Number Inconsistent Answers & & $\begin{array}{c}-1.142 \\
(0.46)^{* *}\end{array}$ & $\begin{array}{c}-1.028 \\
(0.43)^{* *}\end{array}$ & $\begin{array}{l}-1.026 \\
(0.41)^{* *}\end{array}$ & $\begin{array}{l}-0.978 \\
(0.41)^{* *}\end{array}$ \\
\hline Impatience & & & $\begin{array}{l}-0.330 \\
(0.20)^{*}\end{array}$ & $\begin{array}{l}-0.443 \\
(0.19)^{* *}\end{array}$ & $\begin{array}{l}-0.538 \\
(0.21)^{* *}\end{array}$ \\
\hline Age & & & & $\begin{array}{c}0.321 \\
(0.07)^{* * *}\end{array}$ & $\begin{array}{c}0.301 \\
(0.07)^{* * *}\end{array}$ \\
\hline Gender & & & & $\begin{array}{l}1.507 \\
(1.29)\end{array}$ & $\begin{array}{c}2.305 \\
(1.35)^{*}\end{array}$ \\
\hline Married & & & & $\begin{array}{l}-0.348 \\
(0.90)\end{array}$ & $\begin{array}{l}-0.781 \\
(1.02)\end{array}$ \\
\hline Number of Children & & & & $\begin{array}{l}-0.247 \\
(0.28)\end{array}$ & $\begin{array}{l}-0.311 \\
(0.30)\end{array}$ \\
\hline Education & & & & $\begin{array}{c}0.851 \\
(0.48)^{*}\end{array}$ & $\begin{array}{l}0.681 \\
(0.51)\end{array}$ \\
\hline Retirement Benefits $[\mathrm{log}]$ & & & & $\begin{array}{l}-0.556 \\
(0.30)^{*}\end{array}$ & $\begin{array}{l}-0.458 \\
(0.27)^{*}\end{array}$ \\
\hline Satisfaction Retirement Benefits & & & & $\begin{array}{c}-0.070 \\
(0.17)\end{array}$ & $\begin{array}{l}-0.039 \\
(0.18)\end{array}$ \\
\hline Risk Aversion & & & & & $\begin{array}{c}-0.349 \\
(0.25)\end{array}$ \\
\hline Loss Aversion & & & & & $\begin{array}{c}-0.026 \\
(0.23)\end{array}$ \\
\hline Financial Literacy & & & & & $\begin{array}{c}-0.980 \\
(0.41)^{* *}\end{array}$ \\
\hline Life Expectancy & & & & & $\begin{array}{c}-0.022 \\
(0.05)\end{array}$ \\
\hline Private Pension Insurance & & & & & $\begin{array}{c}0.113 \\
(0.60)\end{array}$ \\
\hline Constant & $\begin{array}{c}62.158 \\
(0.34)^{* * *}\end{array}$ & $\begin{array}{c}62.195 \\
(0.34)^{* * *}\end{array}$ & $\begin{array}{c}63.401 \\
(0.76)^{* * *}\end{array}$ & $\begin{array}{c}45.331 \\
(4.66)^{* * *}\end{array}$ & $\begin{array}{c}53.353 \\
(7.72)^{* * *} \\
\end{array}$ \\
\hline $\mathrm{R}^{2}$ & 0.028 & 0.046 & 0.056 & 0.250 & 0.278 \\
\hline Observations & 185 & 185 & 185 & 169 & 160 \\
\hline
\end{tabular}

Notes: The table shows the results of five OLS regressions with Actual Retirement Age in years as the dependent variable. Independent variables are as defined in the Appendix. Robust standard errors are displayed in parentheses. ${ }^{* * *},{ }^{* *}$, and ${ }^{*}$ indicate statistical significance at the $1 \%, 5 \%$, and $10 \%$-level, respectively. 
Table 4

Ex-post evaluation of the retirement decision

\begin{tabular}{|c|c|c|c|c|c|}
\hline & \multicolumn{5}{|c|}{ Retirement Regret } \\
\hline & (1) & $(2)$ & (3) & $(4)$ & $(5)$ \\
\hline Inconsistency Indicator & $\begin{array}{c}0.188 \\
(0.07)^{* * *}\end{array}$ & & & & \\
\hline Number Inconsistent Answers & & $\begin{array}{c}0.097 \\
(0.04)^{* * *}\end{array}$ & $\begin{array}{c}0.097 \\
(0.04)^{* *}\end{array}$ & $\begin{array}{c}0.097 \\
(0.04)^{* *}\end{array}$ & $\begin{array}{c}0.079 \\
(0.04)^{* *}\end{array}$ \\
\hline Impatience & & & $\begin{array}{c}0.001 \\
(0.02)\end{array}$ & $\begin{array}{c}-0.005 \\
(0.02)\end{array}$ & $\begin{array}{c}-0.006 \\
(0.02)\end{array}$ \\
\hline Actual Retirement Age & & & & $\begin{array}{c}0.000 \\
(0.01)\end{array}$ & $\begin{array}{c}-0.002 \\
(0.01)\end{array}$ \\
\hline Age & & & & $\begin{array}{c}-0.001 \\
(0.01)\end{array}$ & $\begin{array}{c}-0.000 \\
(0.01)\end{array}$ \\
\hline Gender & & & & $\begin{array}{c}-0.100 \\
(0.13)\end{array}$ & $\begin{array}{c}-0.061 \\
(0.14)\end{array}$ \\
\hline Married & & & & $\begin{array}{c}-0.037 \\
(0.10)\end{array}$ & $\begin{array}{c}-0.088 \\
(0.11)\end{array}$ \\
\hline Number of Children & & & & $\begin{array}{c}0.004 \\
(0.03)\end{array}$ & $\begin{array}{l}0.000 \\
(0.03)\end{array}$ \\
\hline Education & & & & $\begin{array}{c}-0.018 \\
(0.04)\end{array}$ & $\begin{array}{c}0.016 \\
(0.04)\end{array}$ \\
\hline Retirement Benefits [log] & & & & $\begin{array}{c}0.030 \\
(0.02)\end{array}$ & $\begin{array}{c}0.025 \\
(0.02)\end{array}$ \\
\hline Satisfaction Retirement Benefits & & & & $\begin{array}{c}-0.059 \\
(0.02)^{* * *}\end{array}$ & $\begin{array}{c}-0.072 \\
(0.02)^{* * *}\end{array}$ \\
\hline Risk Aversion & & & & & $\begin{array}{l}0.019 \\
(0.02)\end{array}$ \\
\hline Loss Aversion & & & & & $\begin{array}{l}0.002 \\
(0.02)\end{array}$ \\
\hline Financial Literacy & & & & & $\begin{array}{c}-0.046 \\
(0.04)\end{array}$ \\
\hline Life Expectancy & & & & & $\begin{array}{c}0.003 \\
(0.00)\end{array}$ \\
\hline Private Pension Insurance & & & & & $\begin{array}{c}-0.048 \\
(0.07)\end{array}$ \\
\hline Constant & $\begin{array}{c}0.150 \\
(0.03)^{* * *}\end{array}$ & $\begin{array}{c}0.161 \\
(0.03)^{* * *}\end{array}$ & $\begin{array}{c}0.156 \\
(0.07)^{* *}\end{array}$ & $\begin{array}{l}0.412 \\
(0.57)\end{array}$ & $\begin{array}{c}0.506 \\
(0.74)\end{array}$ \\
\hline $\mathrm{R}^{2}$ & 0.043 & 0.042 & 0.036 & 0.082 & 0.099 \\
\hline Observations & 185 & 185 & 185 & 167 & 158 \\
\hline
\end{tabular}

Notes: The table shows the results of five linear probability models (OLS) with the indicator Retirement Regret as the dependent variable. Robust standard errors are displayed in parentheses. ${ }^{* * *},{ }^{* *}$, and ${ }^{*}$ indicate statistical significance at the $1 \%, 5 \%$, and $10 \%$-level, respectively. 
Table 5

Effect of time preferences on planned retirement age

\begin{tabular}{|c|c|c|c|c|c|c|}
\hline & \multicolumn{6}{|c|}{ Planned Retirement Age } \\
\hline & (1) & (2) & (3) & (4) & (5) & (6) \\
\hline Inconsistency Indicator & $\begin{array}{c}-0.365 \\
(0.17)^{* *}\end{array}$ & $\begin{array}{l}-0.327 \\
(0.17)^{*}\end{array}$ & & & $\begin{array}{c}-0.141 \\
(0.16)\end{array}$ & $\begin{array}{c}-0.206 \\
(0.16)\end{array}$ \\
\hline Impatience & & $\begin{array}{c}-0.172 \\
(0.05)^{* * *}\end{array}$ & & $\begin{array}{c}-0.172 \\
(0.05)^{* * *}\end{array}$ & $\begin{array}{c}-0.181 \\
(0.05)^{* * *}\end{array}$ & $\begin{array}{c}-0.158 \\
(0.05)^{* * *}\end{array}$ \\
\hline Number Inconsistent Answers & & & $\begin{array}{c}-0.236 \\
(0.08)^{* * *}\end{array}$ & $\begin{array}{c}-0.221 \\
(0.08)^{* * *}\end{array}$ & & \\
\hline Age & & & & & $\begin{array}{c}-0.053 \\
(0.01)^{* * *}\end{array}$ & $\begin{array}{l}-0.026 \\
(0.01)^{*}\end{array}$ \\
\hline Age x Incon. Indicator & & & & & $\begin{array}{c}-0.034 \\
(0.01)^{* * *}\end{array}$ & $\begin{array}{c}-0.032 \\
(0.01)^{* *}\end{array}$ \\
\hline Gender & & & & & & $\begin{array}{c}-0.038 \\
(0.23)\end{array}$ \\
\hline Married & & & & & & $\begin{array}{l}-0.395 \\
(0.21)^{*}\end{array}$ \\
\hline Number of Children & & & & & & $\begin{array}{c}0.051 \\
(0.14)\end{array}$ \\
\hline Education & & & & & & $\begin{array}{c}0.495 \\
(0.13)^{* * *}\end{array}$ \\
\hline Income $[\log ]$ & & & & & & $\begin{array}{c}-0.447 \\
(0.13)^{* * *}\end{array}$ \\
\hline Risk Aversion & & & & & & $\begin{array}{l}0.091 \\
(0.08)\end{array}$ \\
\hline Loss Aversion & & & & & & $\begin{array}{l}-0.127 \\
(0.07)^{*}\end{array}$ \\
\hline Financial Literacy & & & & & & $\begin{array}{c}-0.122 \\
(0.08)\end{array}$ \\
\hline Life Expectancy & & & & & & $\begin{array}{c}0.042 \\
(0.02)^{* *}\end{array}$ \\
\hline Private Pension Insurance & & & & & & $\begin{array}{c}-0.552 \\
(0.17)^{* * *}\end{array}$ \\
\hline Constant & $\begin{array}{c}65.114 \\
(0.11)^{* * *}\end{array}$ & $\begin{array}{c}65.763 \\
(0.22)^{* * *}\end{array}$ & $\begin{array}{c}65.123 \\
(0.10)^{* * *}\end{array}$ & $\begin{array}{c}65.780 \\
(0.22)^{* * *}\end{array}$ & $\begin{array}{c}67.862 \\
(0.45)^{* * *}\end{array}$ & $\begin{array}{c}67.155 \\
(2.19)^{* * *}\end{array}$ \\
\hline $\mathrm{R}^{2}$ & 0.002 & 0.006 & 0.003 & 0.008 & 0.057 & 0.074 \\
\hline Observations & 2111 & 2104 & 2111 & 2104 & 2104 & 2046 \\
\hline
\end{tabular}

Notes: The table shows the results of six OLS regressions with Planned Retirement Age as the dependent variable. All variables are as defined in the Appendix. Age x Incon. Indicator is the interaction between age and the inconsistency indicator. Robust standard errors are displayed in parentheses. ${ }^{* * *},{ }^{* *}$, and ${ }^{*}$ indicate statistical significance at the $1 \%, 5 \%$, and $10 \%$-level, respectively. 
Table 6

Effect of time preferences on planned retirement age - sample split

\begin{tabular}{|c|c|c|c|c|c|c|}
\hline & \multicolumn{6}{|c|}{ Planned Retirement Age } \\
\hline & \multicolumn{2}{|c|}{ Age $\leq$ Median } & \multicolumn{2}{|c|}{ Age $>$ Median } & $\begin{array}{c}\text { Age }>50 \\
(5)\end{array}$ & $\begin{array}{c}\text { Age }>55 \\
(6)\end{array}$ \\
\hline Number Inconsistent Answers & $\begin{array}{c}0.201 \\
(0.12)^{*}\end{array}$ & $\begin{array}{l}0.125 \\
(0.12)\end{array}$ & $\begin{array}{c}-0.458 \\
(0.14)^{* * *}\end{array}$ & $\begin{array}{c}-0.446 \\
(0.14)^{* * *}\end{array}$ & $\begin{array}{c}-0.774 \\
(0.18)^{* * *}\end{array}$ & $\begin{array}{c}-0.988 \\
(0.29)^{* * *}\end{array}$ \\
\hline Impatience & $\begin{array}{c}-0.286 \\
(0.07)^{* * *}\end{array}$ & $\begin{array}{c}-0.246 \\
(0.07)^{* * *}\end{array}$ & $\begin{array}{c}-0.124 \\
(0.08)\end{array}$ & $\begin{array}{r}-0.127 \\
(0.08)\end{array}$ & $\begin{array}{c}-0.114 \\
(0.10)\end{array}$ & $\begin{array}{c}-0.243 \\
(0.15)\end{array}$ \\
\hline Age & & $\begin{array}{l}0.021 \\
(0.04)\end{array}$ & & $\begin{array}{c}-0.011 \\
(0.02)\end{array}$ & $\begin{array}{c}-0.049 \\
(0.06)\end{array}$ & $\begin{array}{c}-0.175 \\
(0.20)\end{array}$ \\
\hline Gender & & $\begin{array}{l}0.054 \\
(0.31)\end{array}$ & & $\begin{array}{l}-0.288 \\
(0.36)\end{array}$ & $\begin{array}{c}-0.808 \\
(0.54)\end{array}$ & $\begin{array}{c}-1.022 \\
(0.73)\end{array}$ \\
\hline Married & & $\begin{array}{l}0.244 \\
(0.41)\end{array}$ & & $\begin{array}{c}-0.739 \\
(0.28)^{* * *}\end{array}$ & $\begin{array}{l}-0.747 \\
(0.39)^{*}\end{array}$ & $\begin{array}{c}-0.494 \\
(0.55)\end{array}$ \\
\hline Number of Children & & $\begin{array}{c}-0.325 \\
(0.46)\end{array}$ & & $\begin{array}{c}0.239 \\
(0.08)^{* * *}\end{array}$ & $\begin{array}{l}0.085 \\
(0.16)\end{array}$ & $\begin{array}{l}0.259 \\
(0.21)\end{array}$ \\
\hline Education & & $\begin{array}{c}0.827 \\
(0.25)^{* * *}\end{array}$ & & $\begin{array}{c}0.225 \\
(0.16)\end{array}$ & $\begin{array}{c}0.700 \\
(0.21)^{* * *}\end{array}$ & $\begin{array}{c}0.548 \\
(0.29)^{*}\end{array}$ \\
\hline Income $[\log ]$ & & $\begin{array}{c}-0.848 \\
(0.20)^{* * *}\end{array}$ & & $\begin{array}{l}-0.181 \\
(0.17)\end{array}$ & $\begin{array}{c}-0.159 \\
(0.22)\end{array}$ & $\begin{array}{l}0.223 \\
(0.22)\end{array}$ \\
\hline Risk Aversion & & $\begin{array}{l}0.096 \\
(0.11)\end{array}$ & & $\begin{array}{l}0.086 \\
(0.10)\end{array}$ & $\begin{array}{c}-0.179 \\
(0.15)\end{array}$ & $\begin{array}{c}-0.258 \\
(0.19)\end{array}$ \\
\hline Loss Aversion & & $\begin{array}{c}-0.225 \\
(0.11)^{* *}\end{array}$ & & $\begin{array}{c}-0.039 \\
(0.09)\end{array}$ & $\begin{array}{l}0.008 \\
(0.13)\end{array}$ & $\begin{array}{l}0.198 \\
(0.17)\end{array}$ \\
\hline Financial Literacy & & $\begin{array}{l}-0.151 \\
(0.11)\end{array}$ & & $\begin{array}{c}-0.113 \\
(0.14)\end{array}$ & $\begin{array}{l}-0.049 \\
(0.19)\end{array}$ & $\begin{array}{l}0.274 \\
(0.28)\end{array}$ \\
\hline Life Expectancy & & $\begin{array}{l}0.016 \\
(0.03)\end{array}$ & & $\begin{array}{c}0.076 \\
(0.02)^{* * *}\end{array}$ & $\begin{array}{l}0.046 \\
(0.03)\end{array}$ & $\begin{array}{c}0.089 \\
(0.04)^{* *}\end{array}$ \\
\hline Private Pension Insurance & & $\begin{array}{c}-0.737 \\
(0.24)^{* * *}\end{array}$ & & $\begin{array}{r}-0.441 \\
(0.28)\end{array}$ & $\begin{array}{c}-0.553 \\
(0.38)\end{array}$ & $\begin{array}{c}-0.614 \\
(0.54)\end{array}$ \\
\hline Constant & $\begin{array}{c}66.810 \\
(0.31)^{* * *}\end{array}$ & $\begin{array}{c}71.423 \\
(2.80)^{* * *}\end{array}$ & $\begin{array}{c}64.881 \\
(0.32)^{* * *}\end{array}$ & $\begin{array}{c}61.319 \\
(2.62)^{* * *}\end{array}$ & $\begin{array}{c}66.565 \\
(4.69)^{* * *}\end{array}$ & $\begin{array}{c}65.873 \\
(12.28)^{* * *}\end{array}$ \\
\hline $\mathrm{R}^{2}$ & 0.014 & 0.058 & 0.013 & 0.041 & 0.074 & 0.139 \\
\hline Observations & 1071 & 1043 & 922 & 897 & 375 & 151 \\
\hline
\end{tabular}

Notes: The table shows six OLS regressions with Planned Retirement Age as the dependent variable. The columns show results for different subsamples by age (participants aged 60 or above are excluded). All variables are as defined in the appendix. Robust standard errors are displayed in parentheses. ${ }^{* * *}$, **, and * indicate statistical significance at the $1 \%, 5 \%$, and $10 \%$-level, respectively. 
Table 7

Effect of time preferences on owning private pension insurance

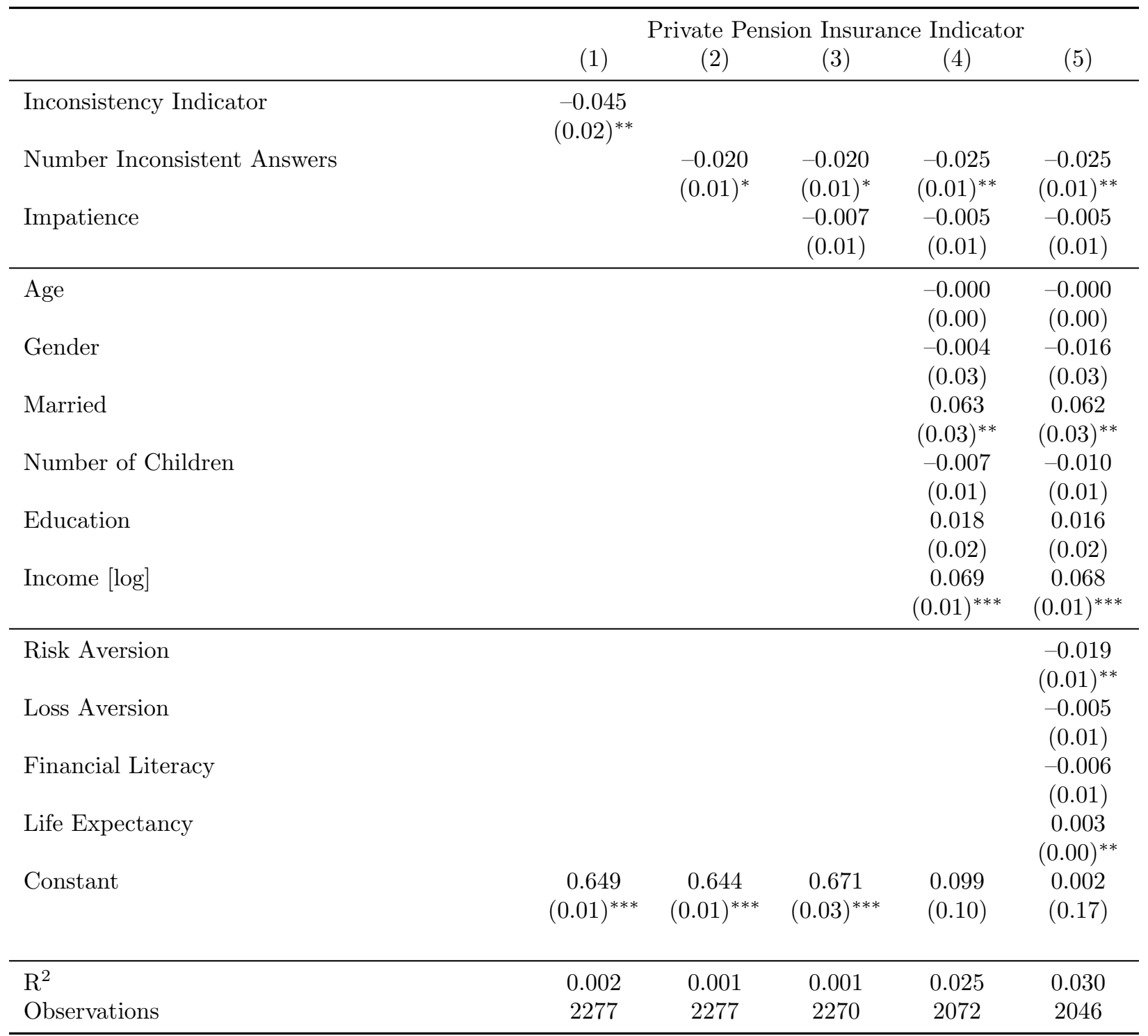

Notes: The table shows the results of five linear probability models with the indicator Private Pension Insurance as the dependent variable. All variables are as defined in the Appendix. Robust standard errors are displayed in parentheses. ${ }^{* * *},{ }^{* *}$, and ${ }^{*}$ indicate statistical significance at the $1 \%, 5 \%$, and $10 \%$-level, respectively. 
Table 8

Summary statistics SAVE survey

\begin{tabular}{|c|c|c|c|c|}
\hline & \multicolumn{2}{|c|}{ Retirees $(\mathrm{n}=907)$} & \multicolumn{2}{|c|}{ Non-Retirees $(\mathrm{n}=1,140)$} \\
\hline & Mean & Std. Dev. & Mean & Std. Dev. \\
\hline \multicolumn{5}{|l|}{ A Retirement Timing } \\
\hline Planned Retirement Age & & & 64.92 & 2.98 \\
\hline Actual Retirement Age & 58.90 & 6.82 & & \\
\hline \multicolumn{5}{|l|}{ B Time Preferences } \\
\hline Smoker $[0-1]$ & 0.14 & 0.35 & 0.31 & 0.46 \\
\hline Overdraft $[1-4]$ & 1.69 & 1.03 & 2.15 & 1.14 \\
\hline Overdraft indicator $[0-1]$ & 0.18 & 0.39 & 0.32 & 0.47 \\
\hline \multicolumn{5}{|l|}{ C Demographics } \\
\hline Age & 69.83 & 8.85 & 46.21 & 19.26 \\
\hline Gender $[$ male $=1]$ & 0.52 & 0.50 & 0.45 & 0.50 \\
\hline Income (if $>0)$ & $1,517.12$ & $1,108.73$ & $1,519.73$ & 985.16 \\
\hline Number of Children & 2.04 & 1.41 & 1.68 & 1.37 \\
\hline Education $[0-2]$ & 0.45 & 0.79 & 0.50 & 0.78 \\
\hline Married & 0.61 & 0.49 & 0.63 & 0.48 \\
\hline \multicolumn{5}{|l|}{ D Additional Controls } \\
\hline Financial Literacy [0-9] & 2.94 & 1.08 & 2.95 & 1.04 \\
\hline Subjective Life Expectancy & 80.33 & 7.06 & 78.60 & 8.40 \\
\hline Private Pension Insurance (PPI) & 0.08 & 0.28 & 0.44 & 0.50 \\
\hline \multicolumn{5}{|l|}{ E Health Controls } \\
\hline Health Status [1-5] & 3.16 & 0.83 & 3.58 & 0.80 \\
\hline Satisfaction Health [0-10] & 5.54 & 2.45 & 6.44 & 2.31 \\
\hline Prolonged Illness & 0.69 & 0.46 & 0.43 & 0.50 \\
\hline
\end{tabular}

Notes: The table presents summary statistics for the SAVE 2010 survey for subsamples of retirees and nonretirees. Variables are as defined in the Appendix. 
Table 9

Actual retirement age SAVE survey

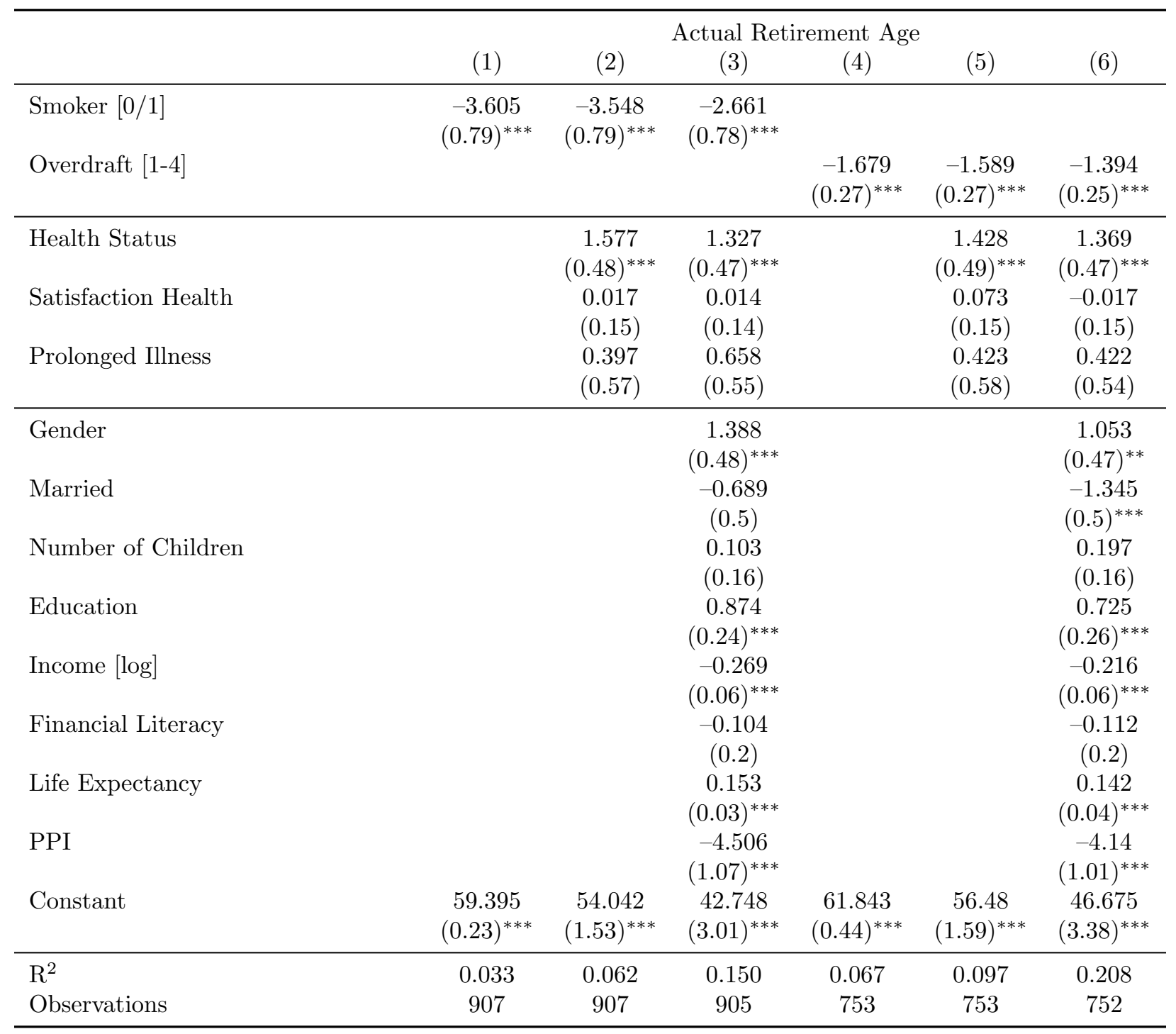

Notes: The table shows the results of six cross-sectional OLS regressions for the 2010 wave of the SAVE survey. The dependent variable is Actual Retirement Age using the subsample of retired participants. Regressions include either smoking or overdraft usage as a proxy for time inconsistency. Variables are as defined in the Appendix. All five imputations of the SAVE data are used. Coefficients and standard errors are calculated according to Rubin (1987). ${ }^{* * *},{ }^{* *}$, and ${ }^{*}$ indicate statistical significance at the $1 \%, 5 \%$, and 10\%-level, respectively. 
Table 10

Planned retirement age SAVE survey

\begin{tabular}{|c|c|c|c|c|c|c|c|}
\hline \multirow[t]{2}{*}{ Panel A } & \multirow{2}{*}{$\begin{array}{c}\text { Full Panel } \\
\text { (1) }\end{array}$} & \multicolumn{3}{|c|}{ Smoker } & \multicolumn{3}{|c|}{ Non-Smoker } \\
\hline & & $\begin{array}{l}\text { All } \\
(2)\end{array}$ & $\begin{array}{c}\text { Age }>40 \\
(3)\end{array}$ & $\begin{array}{c}\text { Age }>50 \\
(4)\end{array}$ & $\begin{array}{l}\text { All } \\
(5)\end{array}$ & $\begin{array}{c}\text { Age }>40 \\
(6)\end{array}$ & $\begin{array}{c}\text { Age }>50 \\
(7)\end{array}$ \\
\hline Wave & $\begin{array}{l}-0.093 \\
(0.05)^{*}\end{array}$ & $\begin{array}{c}-0.197 \\
(0.09)^{* *}\end{array}$ & $\begin{array}{c}-0.256 \\
(0.12)^{* *}\end{array}$ & $\begin{array}{c}-0.321 \\
(0.15)^{* *}\end{array}$ & $\begin{array}{c}-0.036 \\
(0.05)\end{array}$ & $\begin{array}{c}-0.055 \\
(0.06)\end{array}$ & $\begin{array}{l}-0.085 \\
(0.09)\end{array}$ \\
\hline Health Status & $\begin{array}{l}0.010 \\
(0.03)\end{array}$ & $\begin{array}{c}-0.011 \\
(0.06)\end{array}$ & $\begin{array}{l}0.006 \\
(0.06)\end{array}$ & $\begin{array}{l}0.046 \\
(0.08)\end{array}$ & $\begin{array}{c}-0.012 \\
(0.04)\end{array}$ & $\begin{array}{l}-0.014 \\
(0.05)\end{array}$ & $\begin{array}{c}0.125 \\
(0.05)^{* *}\end{array}$ \\
\hline Satisf. Health & $\begin{array}{c}-0.100 \\
(0.14)\end{array}$ & $\begin{array}{l}0.028 \\
(0.27)\end{array}$ & $\begin{array}{c}-0.003 \\
(0.28)\end{array}$ & $\begin{array}{c}-0.074 \\
(0.34)\end{array}$ & $\begin{array}{c}-0.165 \\
(0.15)\end{array}$ & $\begin{array}{c}-0.131 \\
(0.14)\end{array}$ & $\begin{array}{c}-0.094 \\
(0.18)\end{array}$ \\
\hline Prolonged Illness & $\begin{array}{l}0.083 \\
(0.13)\end{array}$ & $\begin{array}{l}-0.067 \\
(0.25)\end{array}$ & $\begin{array}{c}-0.198 \\
(0.32)\end{array}$ & $\begin{array}{c}-0.403 \\
(0.53)\end{array}$ & $\begin{array}{c}0.19 \\
(0.14)\end{array}$ & $\begin{array}{l}0.122 \\
(0.15)\end{array}$ & $\begin{array}{c}-0.073 \\
(0.2)\end{array}$ \\
\hline Constant & $\begin{array}{c}65.572 \\
(0.56)^{* * *}\end{array}$ & $\begin{array}{c}66.696 \\
(1.15)^{* * *}\end{array}$ & $\begin{array}{c}67.091 \\
(1.46)^{* * *}\end{array}$ & $\begin{array}{c}67.681 \\
(2.29)^{* * *}\end{array}$ & $\begin{array}{c}64.883 \\
(0.55)^{* * *}\end{array}$ & $\begin{array}{c}64.961 \\
(0.58)^{* * *}\end{array}$ & $\begin{array}{c}64.702 \\
(0.78)^{* * *}\end{array}$ \\
\hline $\mathrm{R}^{2}$ & 0.003 & 0.007 & 0.011 & 0.033 & 0.003 & 0.003 & 0.014 \\
\hline Obs & 4,043 & 1,449 & 990 & 436 & 2,594 & 1,802 & 952 \\
\hline \multirow[t]{2}{*}{ Panel B } & \multirow{2}{*}{$\begin{array}{c}\text { Full Panel } \\
(1)\end{array}$} & \multicolumn{3}{|c|}{ Overdraft $=1$} & \multicolumn{3}{|c|}{ Overdraft $=0$} \\
\hline & & $\begin{array}{l}\text { All } \\
(2)\end{array}$ & $\begin{array}{c}\text { Age }>40 \\
(3)\end{array}$ & $\begin{array}{c}\text { Age }>50 \\
(4)\end{array}$ & $\begin{array}{l}\text { All } \\
(5)\end{array}$ & $\begin{array}{c}\text { Age }>40 \\
(6)\end{array}$ & $\begin{array}{c}\text { Age }>50 \\
(7)\end{array}$ \\
\hline Wave & $\begin{array}{l}-0.093 \\
(0.05)^{*}\end{array}$ & $\begin{array}{l}-0.111 \\
(0.09)\end{array}$ & $\begin{array}{l}-0.183 \\
(0.11)^{*}\end{array}$ & $\begin{array}{c}-0.236 \\
(0.15)\end{array}$ & $\begin{array}{c}-0.086 \\
(0.06)\end{array}$ & $\begin{array}{c}-0.098 \\
(0.07)\end{array}$ & $\begin{array}{c}-0.125 \\
(0.09)\end{array}$ \\
\hline Health Status & $\begin{array}{l}0.010 \\
(0.03)\end{array}$ & $\begin{array}{l}0.049 \\
(0.06)\end{array}$ & $\begin{array}{l}-0.021 \\
(0.06)\end{array}$ & $\begin{array}{l}0.093 \\
(0.09)\end{array}$ & $\begin{array}{l}-0.038 \\
(0.04)\end{array}$ & $\begin{array}{l}0.005 \\
(0.05)\end{array}$ & $\begin{array}{c}0.112 \\
(0.05)^{* *}\end{array}$ \\
\hline Satisf. Health & $\begin{array}{c}-0.100 \\
(0.14)\end{array}$ & $\begin{array}{c}-0.249 \\
(0.25)\end{array}$ & $\begin{array}{c}-0.238 \\
(0.21)\end{array}$ & $\begin{array}{c}-0.199 \\
(0.28)\end{array}$ & $\begin{array}{c}-0.008 \\
(0.16)\end{array}$ & $\begin{array}{c}-0.014 \\
(0.18)\end{array}$ & $\begin{array}{c}-0.026 \\
(0.2)\end{array}$ \\
\hline Prolonged Illness & $\begin{array}{c}0.083 \\
(0.13)\end{array}$ & $\begin{array}{l}0.031 \\
(0.18)\end{array}$ & $\begin{array}{r}-0.051 \\
(0.18)\end{array}$ & $\begin{array}{c}-0.047 \\
(0.29)\end{array}$ & $\begin{array}{l}0.101 \\
(0.18)\end{array}$ & $\begin{array}{l}0.015 \\
(0.22)\end{array}$ & $\begin{array}{c}-0.281 \\
(0.32)\end{array}$ \\
\hline Constant & $\begin{array}{c}65.572 \\
(0.56)^{* * *}\end{array}$ & $\begin{array}{c}65.616 \\
(0.93)^{* * *}\end{array}$ & $\begin{array}{c}66.579 \\
(1.08)^{* * *}\end{array}$ & $\begin{array}{c}65.726 \\
(1.43)^{* * *}\end{array}$ & $\begin{array}{c}65.591 \\
(0.69)^{* * *}\end{array}$ & $\begin{array}{c}65.360 \\
(0.85)^{* * *}\end{array}$ & $\begin{array}{c}65.721 \\
(1.28)^{* * *}\end{array}$ \\
\hline $\mathrm{R}^{2}$ & 0.003 & 0.006 & 0.008 & 0.022 & 0.002 & 0.002 & 0.014 \\
\hline Obs & 4,043 & 1,356 & 924 & 411 & 2,687 & 1,868 & 977 \\
\hline
\end{tabular}

Notes: The table shows the results of seven fixed-effects panel regressions with Planned Retirement Age in years as the dependent variable. Data used for the analysis come from SAVE 2008, 2009, 2010, and 2011, encoded in the variable Wave. All variables are as defined in the Appendix. All five imputations of the SAVE data are used. Coefficients and standard errors are calculated according to Rubin (1987). ${ }^{* * *},{ }^{* *}$, and ${ }^{*}$ indicate statistical significance at the $1 \%, 5 \%$, and $10 \%$-level, respectively. 
The following questions are about your personal preference. There are no right or wrong answers.

Suppose you receive a tax refund. You are given two options regarding the point in time when the payment is transferred to you. If you choose option A the money is transferred to you earlier compared to option B. If you choose option B you will receive the money later. Please indicate for all six situations which option you would prefer.
A: you receive $1,100 €$ immediately
A: you receive $1,100 €$ in 18 months
B: you receive $1,130 €$ in 10 months
B: you receive $1,130 €$ in $\mathbf{2 8}$ months
A: you receive $1,100 €$ immediately
A: you receive $1,100 €$ in 18 months
B: you receive $1,200 €$ in 10 months
B: you receive $1,200 €$ in $\mathbf{2 8}$ months
A: you receive $1,100 €$ immediately
A: you receive $1,100 €$ in $\mathbf{1 8}$ months
B: you receive $1,380 €$ in 10 months
B: you receive $1,380 €$ in $\mathbf{2 8}$ months

\section{Figure 1}

Time preference survey questions

Notes: Screenshot of the survey question used to elicit time preferences. Displayed are six choices between a smaller sooner amount and a later larger amount. Time consistency requires the same choice (A or B) on the right and the left. 


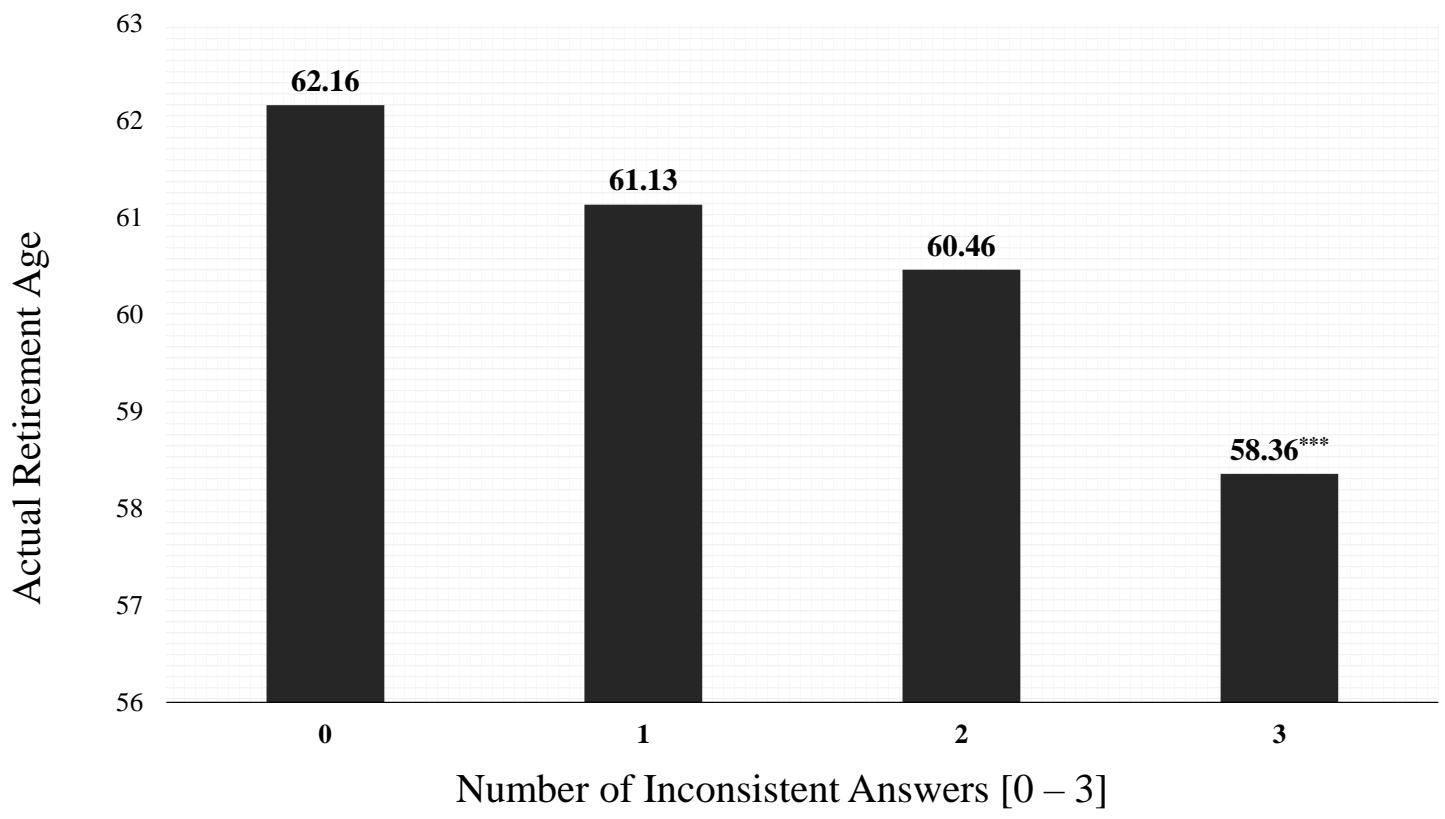

\section{Figure 2}

Average actual retirement age by number of inconsistent answers

Notes: The bars show the average actual retirement age for participants with $0,1,2$, or 3 inconsistent answers. ${ }^{* * *},{ }^{* *}$, and ${ }^{*}$ indicate a significant difference on the $1 \%, 5 \%$, and $10 \%$ levels relative to the group with zero inconsistent answers. 


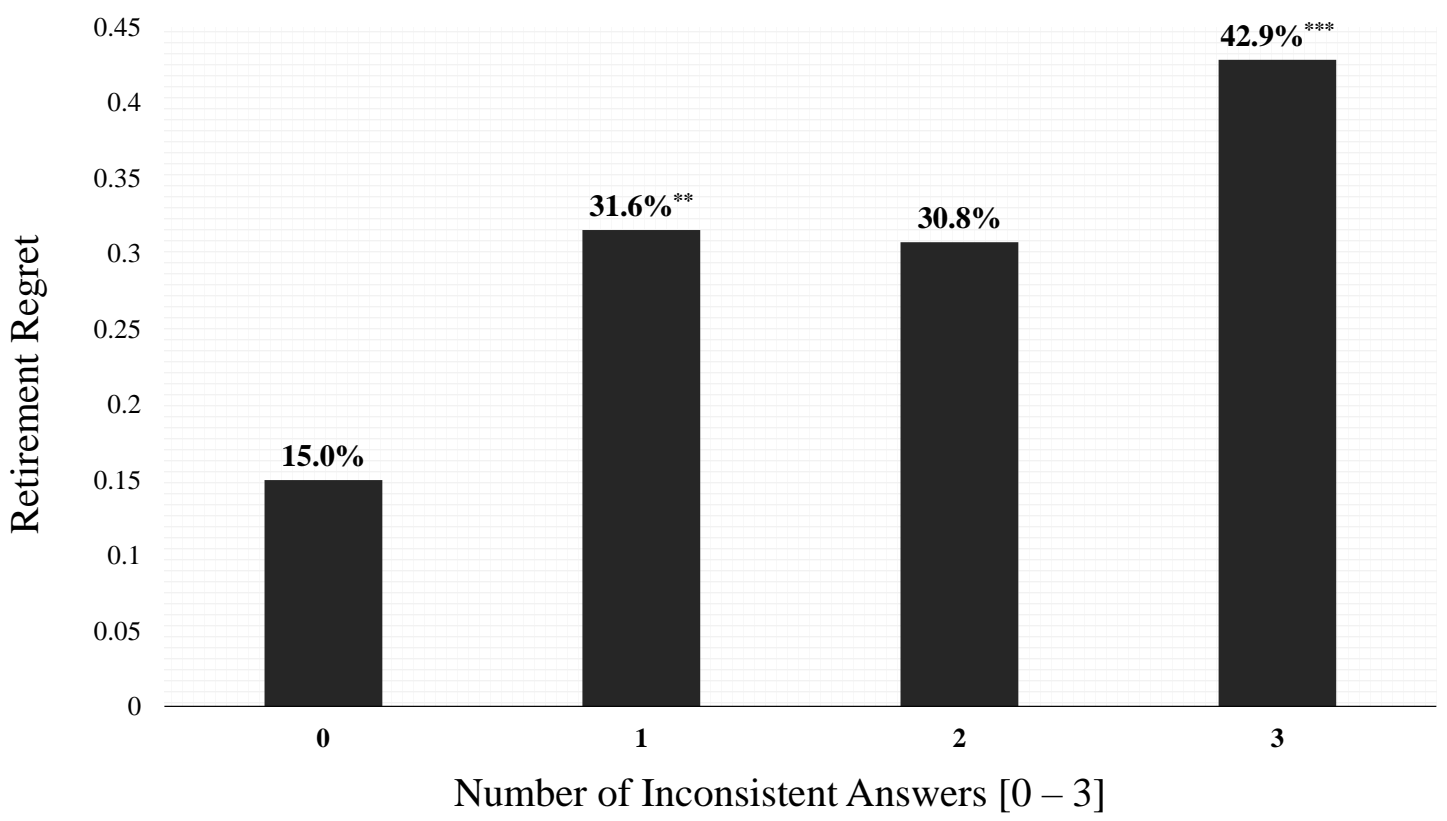

Figure 3

Fraction of participants stating they retired too early

Notes: The bars show the fraction of participants who state they retired too early for participants with 0 , 1, 2 or 3 inconsistent answers. ${ }^{* * *},{ }^{* *}$, and ${ }^{*}$ indicate a significant difference on the $1 \%, 5 \%$, and $10 \%$ levels relative to the group with zero inconsistent answers. 


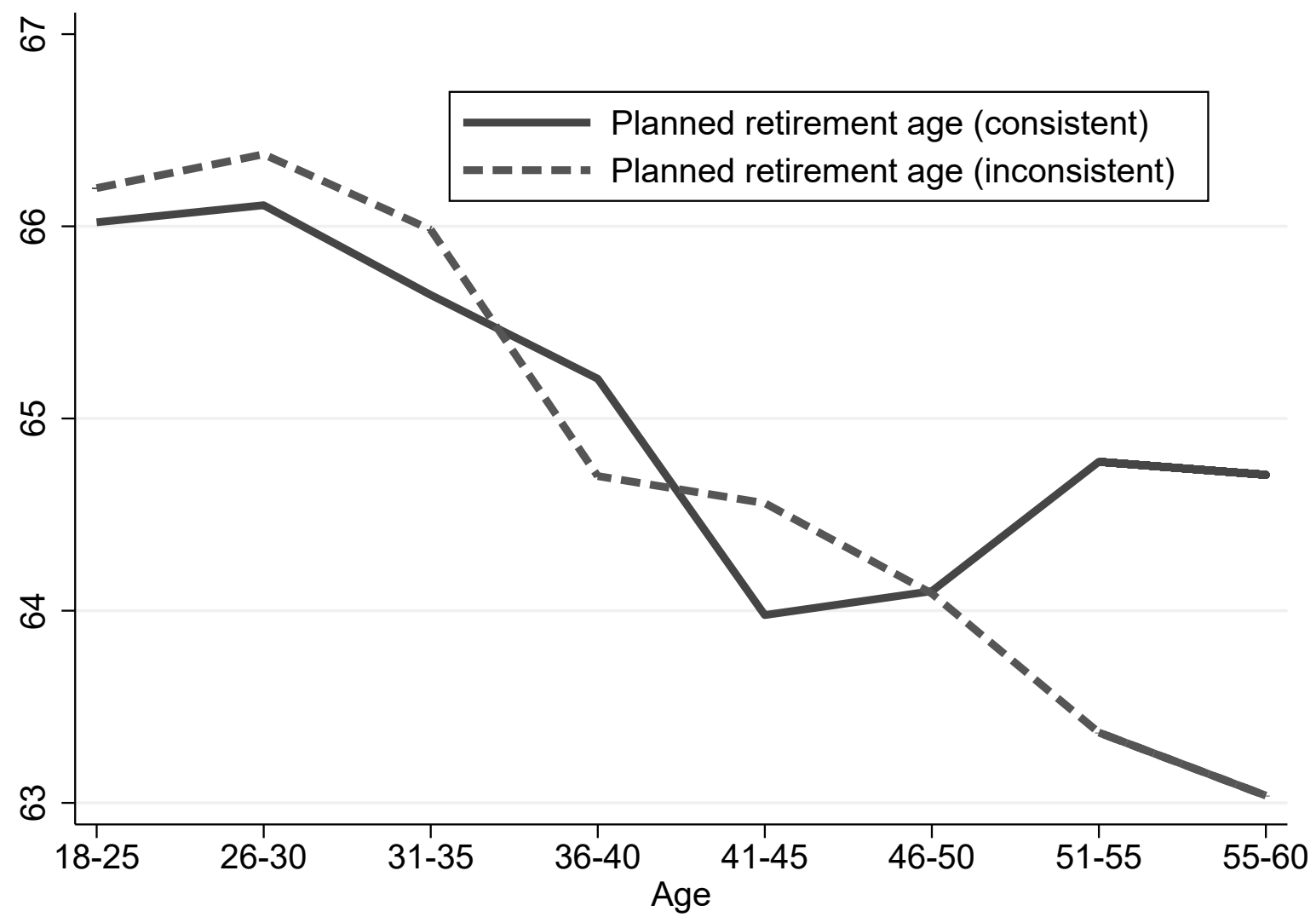

Figure 4

Planned retirement age by age group and time preferences

Notes: The figure shows the average planned retirement age depending on current age for time-consistent participants (solid line) and for time-inconsistent participants (dashed line). 

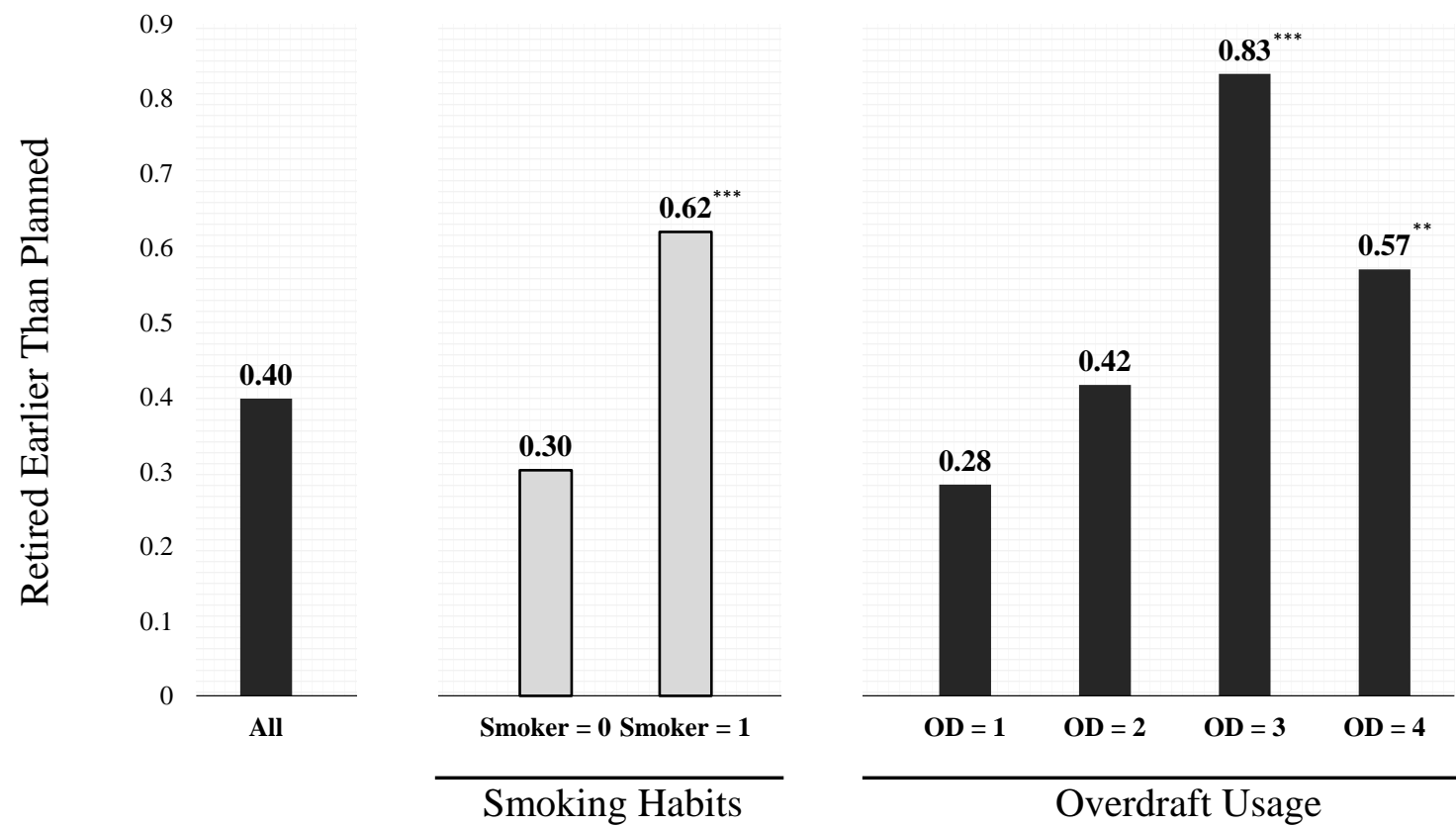

\section{Figure 5}

Retirement timing by overdraft usage and smoking habits

Notes: The figure shows the fraction of participants who retire earlier than planned in the SAVE waves 2008-2011. Earlier than planned retirement is assumed if the planned retirement age in wave t-1 $\left(P R A_{t-1}\right)$ is larger than the actual retirement age indicated in wave $\mathrm{t}\left(A R A_{t}\right) .{ }^{* * *},{ }^{* *}$, and ${ }^{*}$ indicate a significant difference on the $1 \%, 5 \%$, and $10 \%$ levels relative to the group of non-smokers or to the group not using overdrafts (overdraft $=1$ ). 